\title{
STUDIES IN THE FUNCTIONAL MORPHOLOGY AND EMBRYOLOGY OF ONCHIDELLA CELTICA (FORBES AND HANLEY) AND THEIR BEARING ON ITS RELATIONSHIPS
}

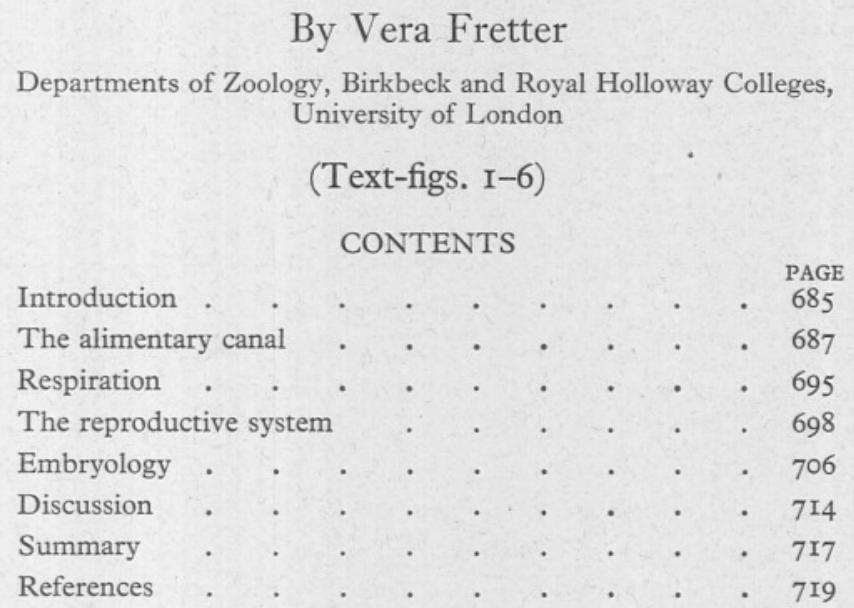

INTRODUCTION

Onchidella celtica, the only British representative of the family Onchidiidae, lives between tide marks in crevices of eroded rocks on the north and south Cornish coasts. Along the exposed southern coast between Rame Head and Looe many of the rocks rise to a steep escarpment on the north side, and here in the sloping crevices, sheltered from wave action and from strong sunlight, the animals are found in considerable numbers. They occur a few feet down from high-water mark, not above it as mentioned by Ellis (I926), and some are found in rocks uncovered only at low tide. They live in communities ranging from two or three individuals to over sixty, and in each community animals of varying ages are found. On warm days, and when uncovered by the ebbing tide, the molluscs emerge from their shelter in search of food, but during the colder months, between November and March, they remain in the rock crevices; then they are very inactive and pass through a period of hibernation. A similar annual period of limited activity is described by Arey \& Crozier (I92I) for Onchidium verruculatum.

When wandering over the rocks Onchidella celtica avoids long exposure to strong sunlight and the wind-swept surfaces; in stormy weather it does not appear. Not every animal emerges at an appropriate tide, though the majority are active on still summer days when the sky is overcast, or there is a heavy sea mist, and then they may browse on the southern slopes of the rocks which 
are not visited in sunny weather. Their food consists of young algae and encrusting diatoms, and in search of these they travel with considerable rapidity: the sensory lobes of the head always in contact with the substrate, the tentacles protruding from under the anterior margin of the mantle, and the posterior edge of the mantle upturned to expose the pulmonary aperture, which is then widely open. They may wander a yard or so from the rock crevice from which they emerged, selecting food at intervals and eating it ravenously, or their journey may only be a few inches; they frequently visit the beds of young mussels or barnacles to rasp the organisms which settle on the shells. At the rising tide the molluscs retreat to their shelter and this they reach before the water covers them. Although some exceptions have been observed, on the whole each animal returns to its own particular crevice, or one near by; the exact path of the outward journey is not retraced. This homing habit has been previously observed in Onchidium floridanum (Arey \& Crozier, I92I), which lives on the shore rocks at Bermuda. The crevice which is chosen may have an extremely small opening to the exterior, is always sandy, and mingled with the sand are diatoms washed in by the waves; these the animals often eat. Forbes \& Hanley (1853), in citing observations made by Mr Couch, state that Onchidella celtica occurs between Polperro and Fowey about a foot or two from the sea, and migrates up and down the shore as the tide rises and falls to maintain its distance from the water. No such migration has ever been seen and the animals appear to live at the same level throughout the year. During the summer months the egg capsules are laid in the rock crevices inhabited by the adults, and within the capsules the embryos develop to a creeping stage which superficially resembles the parent.

The anatomy and development of $O$. celtica have been described by JoyeuxLaffuie (1882). This is the only member of the Onchidiidae in which the development has been studied. No sections were made of the embryos and this probably accounts for his misinterpretation of some points in their structure, and his failure to elucidate from the development certain features in the anatomy of the adult. A little histology of the alimentary and reproductive systems of the adult is given, but the correlation between the structure and function of the various organs is only slight. Although Joyeux-Laffuie mistook the lung of $O$. celtica for a kidney which had acquired some respiratory function, yet he recognized the mollusc as a pulmonate which in some features approached the nudibranchs; with this Brock (1883) agreed. Since Cuvier (I804) described the anatomy of Onchidium Peronii and pointed out its close resemblance to the slugs, most investigators have accepted the Onchidiidae as pulmonates, though their exact affinities within this subclass have been subject to controversy; in a number of characters they stand isolated from the air-breathing molluscs. Bergh (1885) states that they are derived from land snails, and represent a terminal twig in the evolution of the Stylommatophora. On the contrary, Plate (1893), who studied the anatomy of several members of the family, concluded that their origin must 
be sought in the tectibranch opisthobranchs, and hence he considers that they are more closely allied to the Basommatophora. Von Wissel (I898) maintains that they approach this order more closely, though he is unable to decide whether they are primitive or degenerate. In a comparatively recent paper Labbé (1934) describes the occurrence of siliceous spicules in the tissues of several members of the Onchidiidae, and he claims strong opisthobranch affinities for the group, consequently he renames it the Silicodermatae and places it under the opisthobranchs. The pulmonates he groups with the prosobranchs and gives the following classification of the gastropods:

Prosobranchs: Prosobranchs sensu stricto; Opisthobranchs: Opisthobranchs sensu stricto; Pulmonates.

Silicodermatae.

The work here recorded was done at the Marine Laboratory, Plymouth, and at Birkbeck and Royal Holloway Colleges. I wish to express my indebtedness to the University of London for the use of their table at the Plymouth Laboratory, and to Birkbeck College for a grant towards the cost of publication.

\section{The Alimentary Canal}

The head lies between the anterior edge of the mantle (Fig. I A, am), which covers it dorsally, and the foot $(f)$, and is separated from the latter by a deep groove which leads to the opening of the pedal mucous gland $(o)$. The mouth $(m)$ is ventral, and when the animal is not feeding it appears as a longitudinal slit, bordered on each side by a muscular and sensory lobe $(s l)$ which has a broad, flat, ventral surface. Dorsal to each lobe is a tentacle $(t)$, black in colour as the rest of the head and bearing an eye (e) at its apex. When the animal is resting in the rock, or if it is disturbed during its perambulations, the tentacles are invaginated and completely withdrawn, and the whole head region may be protected by the anterior border of the foot covering it ventrally. The mouth leads into a short oral tube which is a ventral prolongation of the buccal cavity and can be closed by a sphincter. The sensory lobes and the oral tube are covered by a cuticularized, columnar epithelium, through which penetrate the ducts of subepithelial glands. Some of these are mucous cells producing secretion for the lubrication of the surfaces; others are plentiful on the sensory lobes and contain small colourless spherules-not dissolved in any fixative, staining black with iron haematoxylin and probably secreting a cement. On the anterior wall of the oral tube, below the point at which it opens into the buccal cavity, the cuticle is thickened to form a transverse ridge with a sharp and slightly irregular summit. The ridge acts as a jaw against which the radula can work, and assists in biting the food which is drawn in by the radula. A mid-dorsal ciliated channel runs down the length of the buccal cavity to the oesophagus, and is separated from the more ventral part of the cavity by a longitudinal fold of connective tissue on each side. The ventral part is covered by cuticularized columnar cells, and its floor is hidden by the odontophore which projects forwards to the oral tube. A large number of mucous cells lie in the 
connective tissue beneath the epithelium and open between the columnar cells. Ventral to the anterior tip of each longitudinal fold is the opening of a salivary duct which passes back and penetrates the buccal musculature; when free from this it swells into a small vesicle which is surrounded by a thick coat of circular muscles, and then runs down the side of the buccal

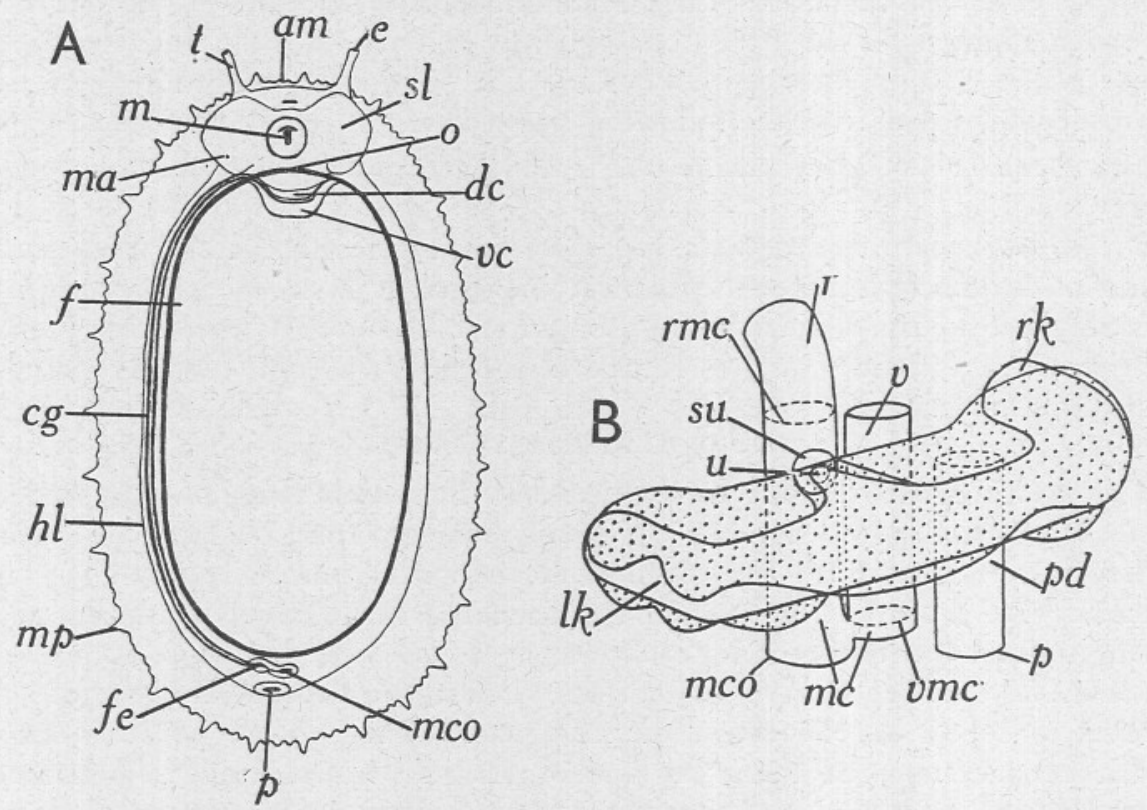

Fig. I. A. Diagrammatic ventral view of Onchidella celtica showing the position of the external apertures and the course of the ciliated groove: $\times 4$. B. Diagram showing the opening of the rectum, secondary ureter and vagina into the mantle cavity, and the position of the pulmonary duct. The stippled area represents the lung wrapped around the kidney: $\times$ about 8 . am, anterior edge of mantle; $c g$, ciliated groove; $d c$, dorsal chamber of pedal mucous gland; $e$, eye; $f$, foot; $f e$, female aperture; $h l$, hyponotal line; $l k$, left limb of kidney; $m$, mouth; ma, male opening situated beneath sensory lobe; $m c$, mantle cavity; $m c o$, opening of mantle cavity previously called anus; $m p$, marginal papilla; $o$, opening of pedal mucous gland; $p$, pneumostome; $p d$, pulmonary duct; $r$, rectum; $r k$, right limb of kidney; $r m c$, opening of rectum into mantle cavity; $s l$, sensory lobe; $s u$, opening of secondary ureter; $t$, tentacle; $u$, opening of primary ureter; $v$, vagina; $v c$, ventral chamber of pedal mucous gland; $v m c$, opening of vagina into mantle cavity.

mass for a short distance to be encircled by the white flocculent lobes of the gland. This spreads ventrally to the nerve ring, to which it is attached by connective tissue. The gland is made up of mucous cells, and scattered rather infrequently among these are secreting cells of a different type: their protoplasm is vacuolated and the vacuoles contain small spherules which stain deeply with iron haematoxylin and orange or red with azan. The cells, all with large nuclei and well-marked nucleoli, are grouped in clusters, and from each of these a short duct opens into the main salivary duct, which is also 
surrounded throughout this part of its course by gland cells. The ducts are ciliated and between the epithelial cells open the surrounding gland cells. Their secretion is passed along the ducts by the cilia, and pumped into the buccal cavity by the muscular vesicle. In the connective tissue which binds the gland cells together are a few muscle fibres.

The two dorso-lateral longitudinal folds of the buccal cavity extend towards the middle line and fuse with one another at their free edges at the beginning of the oesophagus, so that the ciliated dorsal channel runs imperceptibly into the oesophagus. This is directed back over the buccal mass and curves ventrally to pass through the nerve ring. Behind the nerve ring it forms a capacious crop which describes a curve to the left before leading back to the stomach. The whole oesophagus is characterized by a well-developed musculature. The lining is thrown into pliable longitudinal folds (Fig. 2, lf) by the variation in thickness of the underlying connective tissue; when the crop is full the folds are completely obliterated. Joyeux-Laffuie (I882) states that they increase the absorbing area, but no absorption takes place in this part of the gut. The epithelium is composed of columnar cells, which are ciliated in the anterior oesophagus as far as a region just behind the nerve ring and in the posterior part of the tube which opens into the stomach; between these two areas the epithelium is cuticularized. The nuclei lie towards the base of the cells, and above them the cytoplasm contains small yellow pigment granules. A large number of mucous cells are distributed in and below the epithelium, most numerous in the anterior oesophagus. Circular and longitudinal muscles run through the connective tissue and radial muscles penetrate the folds; the circular muscles form a sphincter around the entrance to the buccal cavity and the stomach.

The structure of the stomach may best be studied when it is filled with food (Fig. 2), for when empty the thin-walled regions are contracted and their full extent is not realized. The most conspicuous feature is the large globular triturating sac or gizzard with its massive dorsal $(d)$ and ventral $(v)$ plates, which are hinged to one another laterally. The oesophagus (oe) does not open directly into this sac, but communicates with its anterior end through the thin-walled initial chamber (ic) of the stomach. This receives anteriorly and dorsally the right $(r d)$ and left $(l d)$ ducts from the corresponding anterior lobes of the digestive gland. The intestine likewise is separated from the gizzard by a distensible pouch, the terminal chamber of the stomach $(t c)$, and this overlies the initial chamber. The terminal chamber opens ventrally into the initial chamber and posteriorly into the gizzard. From each of the two anterior digestive gland ducts emerges a fold, the two folds running back parallel with one another along the dorsal wall of the initial chamber and then curving dorsally into the terminal chamber, along the ventral wall of which they pass forwards. These longitudinal folds, separated only by a deep gulley, terminate in a small caecum (c) which occupies a mid-ventral position at the origin of the intestine $(i)$. The left one is larger than the right 
and curves around the left and posterior margins of the opening of the caecum before entering it; the right fold runs straight into the pouch. The excretory matter from the anterior ducts of the digestive gland is directed along the folds and so by-passes the triturating stomach. Similar longitudinal folds are described and figured by Plate (I893) for Onchidium verruculatum, and their occurrence in such diverse groups of the gastropods as chitons (Fretter, I937), Patella (Graham, I932) and tectibranchs (Fretter, 1939) suggests that they constitute one of the characteristic features of the gastropod stomach. There is a third liver duct in Onchidella ( $p d$ ) which arises from the distensible posterior wall ( $p w)$ of the gizzard, and passes ventrally to the smallest of the three lobes. The excretory matter from this less important duct has no directed course to the intestine. When the stomach is empty it can be seen that the longitudinal folds of the oesophagus (lf) continue down the ventral and lateral walls of the initial chamber. This is ciliated and rich in mucous cells; in histological detail and in musculature it resembles the posterior oesophagus. The histology and musculature of the terminal chamber is also similar, but the epithelium is more deeply folded. The folds $(f t)$ arise at the opening into the triturating stomach and pass to the region of the caecum, where they end abruptly. Epithelial mucous cells are frequent, increasing in number towards the caecum, in which they are sufficiently numerous to alternate with the ciliated columnar cells. Their cytoplasm, which is vacuolated and contains

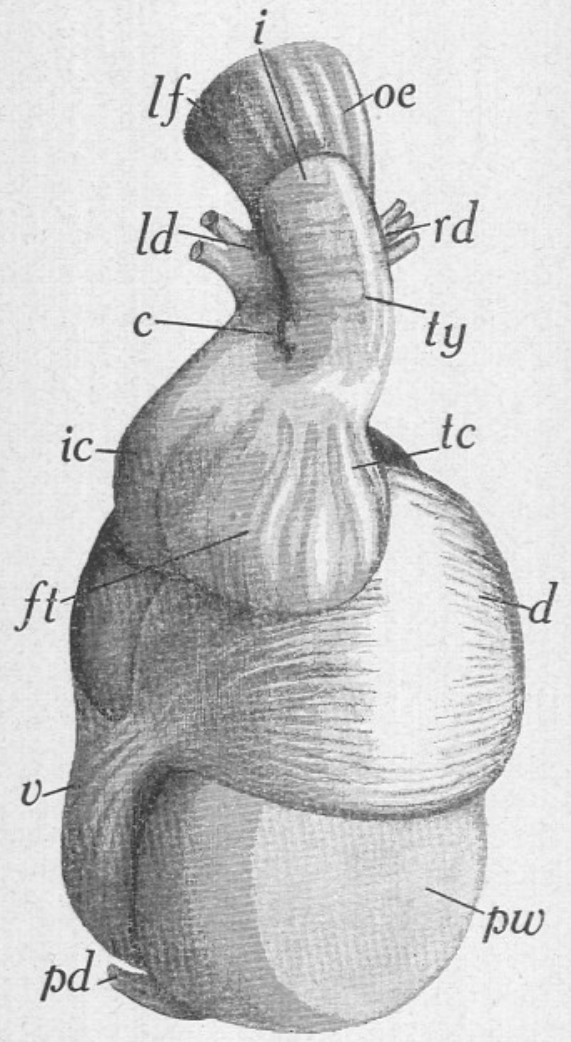

Fig. 2. Distended stomach seen from above and slightly to the left: $\times 17$. c, caecum; $d$, dorsal plate; $f t$, longitudinal fold of terminal chamber; $i$, intestine; $i c$, initial chamber; $l d$, left duct of digestive gland; If, longitudinal fold of oesophagus; oe, oesophagus; $p d$, posterior duct of digestive gland; $p w$, distensible posterior wall; $r d$, right duct of digestive gland; $t c$, terminal chamber; $t y$, typhlosole; $v$, ventral plate. small colourless secretion spherules, stains with iron haematoxylin; it is little affected by mucicarmine, though the discharged secretion, which usually fills the pouch, is susceptible to this stain. The nuclei of the secreting cells are round, basal and nucleolated. The caecum is muscular and the muscle fibres are mainly circular in direction. The dorsal gizzard plate $(d)$ lies anterior to the ventral one $(v)$. Their crushing surfaces are covered by a smooth cuticle, and the 
subepithelial tissue comprises alternating bands of circular and longitudinal muscles. Laterally the muscle layers are thin and are covered externally by compact connective tissue which binds the two plates together. Elsewhere the walls of the gizzard are lined by columnar ciliated cells, and are thrown into deep longitudinal folds when the stomach is empty; a thick layer of circular and longitudinal muscles surrounds the epithelium and assists the triturating action. In the epithelium which secretes the thick cuticle of the plates the cytoplasm is vacuolated, and immediately above the basal nuclei it contains, in each cell, a small clump of darkly staining spherules; distally a few pigment granules may be seen-these are most distinct in young animals in which the cuticle is thin. Fibrillae run through the cytoplasm and merge into the most recently secreted cuticle, which stains lightly with iron haematoxylin and blue with azan. The older part has a different staining reaction and is black after iron haematoxylin and red with azan.

The digestive gland lies dorsal to the reproductive organs and for the most part anterior to them. Of the three lobes the posterior one is by far the smallest; it embraces the posterior wall of the triturating stomach and spreads beneath it. The right and left anterior lobes extend anteriorly as far as the buccal mass, covering on their respective sides the oesophagus and stomach, and the right mass forms a packing for the coils of the intestine. Blood vessels, opaque white in colour since they are coated in tissue rich in crystals of some calcium salt, branch over the surface of the gland. The epithelium is composed of three types of cells arranged according to a definite plan. The most frequent type is the digestive cell, which lines the tubules except in the crypts at the angles of the wall, and here the two other types, the excretory and lime cells, occur exclusively. The digestive cell arises from a narrow base to a height which exceeds that of the other cells. The distal border is regular and slightly rounded in starved animals, but in animals which have recently fed it has an irregular outline. The cytoplasm is vacuolated throughout and the oval nucleus, with a very definite nucleolus, lies towards the base. The vacuoles are smallest at the free ends of the cells, where the cytoplasm is more dense, and they increase in size proximally. The tiny vacuoles contain colourless secretory spherules, and the deeper ones are filled with brown or green particles which, immediately above and below the nucleus, may be aggregated into large clumps. Fat droplets are also found in vacuoles in the more distal cytoplasm. In the crypts, which are constricted off from the rest of the tubule so as to project into the haemocoel, the excretory cells are frequently clustered around the lime cells. They are club-shaped with a rounded free end and are taller than the lime cells which are triangular in longitudinal section with a broad base. The cytoplasm of the excretory cells is vacuolated and the vacuoles contain brown homogeneous spherules of excretory matter which are not dissolved in any fixative. They vary in size: there may be a large number of tiny brown spherules in one cell, or fewer spherules of a larger dimension, or all may be fused into one dark brown 
clump. The nucleus lies beneath the excretory masses, and is readily distinguished from the nucleus of the lime cell which is larger and has a more prominent nucleolus. In the lime cells the cytoplasm is dense and very vacuolated, and the vacuoles are filled with lime spherules.

From the terminal chamber of the stomach the intestine passes over the surface of the digestive gland, and just beneath the buccal mass, to the right side of the body cavity. It dips ventrally under the anterior aorta and then curves dorsally again to describe an anterior U-shaped loop. From this it leads back, above the digestive gland and the reproductive organs, to a midventral opening behind the posterior edge of the foot. The intestine possesses throughout its length a dorsal typhlosole (Fig. 2, ty) which arises opposite the ventral caecum of the stomach. The epithelium is thrown into folds which, together with the typhlosole, are formed by variations in the thickness of the underlying connective tissue. In the anterior part of the intestine, and up to the point at which it passes beneath the aorta, folds arise on either side of the typhlosole, and each runs obliquely backwards around the lateral wall to terminate mid-ventrally. In the posterior part of the tube the folds are directed longitudinally and, except in the rectum, are less pronounced. The columnar ciliated epithelium is taller over the typhlosole than elsewhere and is rich in gland cells. These are of two kinds-mucous cells and clubshaped cells which are filled with small spherules and have a more limited distribution: few are found at the anterior end of the intestine, they increase in number towards the dorsal loop, in which they are numerous, and beyond this are entirely lacking. The spherules stain black with iron haematoxylin and red with azan: when secreted they swell to form a white viscid fluid which binds together the faecal matter. Such cells are not found in the epithelium of the typhlosole. Mucous cells occur in all parts of the epithelium; they are most abundant in the anterior intestine and some lie in the connective tissue beneath the typhlosole. The cytoplasm of the ciliated cells contains small pigment granules which impart to the wall its yellowish brown colour. A double muscular coat consisting of inner circular and outer longitudinal layers surrounds the epithelium, and radial muscles run through the connective tissue of the folds.

When the animal starts off on its feeding foray the crop and stomach are empty of food, containing only a brownish fluid, with a few sand grains in the triturating stomach; when it returns both are fully distended and the contents consist mainly of pieces of algae-filaments up to a centimetre or more in length-and innumerable diatoms. Mixed with these there may be scraps of sponges, foraminiferans such as Polystomella and Gromia, and a mass of sand and detritus. The food is rasped from the rock surface and drawn into the dorsal part of the buccal cavity by the radula, while the sensory lobes take a firm grip of the feeding ground to anchor the head in position. The radula works against the chitinous jaw and is lubricated by a copious secretion of saliva. The viscid salivary fluid also binds together the 
food particles. The cilia on the dorsal channel and the anterior oesophagus help to direct the food into the crop, although here, as in other parts of the gut, its passage is mainly effected by muscular action. It is passed into the stomach as more food is taken in, and both regions of the gut act as a storage place; the contents are digested at leisure during the full tide.

The lumina of the tubules of the digestive gland rarely contain any particulate matter: a few diatom cases may be found there, but these are not taken up by the cells of the gland-in fact no particulate matter appears to be ingested. In animals which have fed on a mixture of diatoms, algal filaments and insoluble iron saccharate the iron has never been traced into the digestive cells, though large quantities are present in the gut and a few particles in the liver tubules. If soluble iron is eaten, it is absorbed by the digestive cells and appears in a very weak solution in the terminal vacuoles. Later it passes to the deeper parts of the cytoplasm and is adsorbed to the green and brown masses which fill the vacuoles-these are apparently accumulations of excretory matter, and at intervals they are expelled from the cells and passed to the intestine. Such observations suggest that only the soluble products of the food are ingested by the digestive gland, and that particulate matter is only carried into the ducts accidentally. Throughout the gut there is no other site of absorption. The ingesting cells have also a secretory function and the free tips of the cells, which contain small spherules, are cut off from the epithelium and pass into the stomach and crop.

An examination of the faeces shows that a large part of the food which is eaten is indigestible since no cellulase appears to be present, and some is undigested. Except for mechanical action the cell walls of the algal filaments are unaffected by their passage through the gut; it is only the contents of cells which have been opened that are utilized. The diatoms constitute a large proportion of the animal's diet and the majority of these are digested, though a number appear in the faeces still with their protoplasmic contents.

The food is crushed by the mechanical action of the stomach; when this is full all the chambers exert pressure on the contents forcing them towards the triturating sac. In this way they are compressed by the dorsal and ventral plates. At the same time the food is mixed with the enzymatic fluid secreted by the digestive gland, so that the available digestible parts are broken down. The soluble products of digestion are wrung from the food and forced into the liver ducts-the two anterior ones receiving the greatest quantity. The fluid is prevented from being regurgitated into the oesophagus by closure of the oesophageal sphincter. Whilst active the gizzard tends to rotate on its longitudinal axis, the dorsal and ventral plates swinging through less than $90^{\circ}$ in a clockwise direction and then back to their original position. Their thick chitinous covering protects the walls against the large number of sand grains which are taken in with the food, and which also help in grinding it. The gizzard is rarely free from sand grains, and Joyeux-Laffuie (I882) considers them to be of such consequence that he likens them to the stones in the 
gizzard of a bird. Heidermanns (I924), in his study of freshwater pulmonates, suggests that the muscular stomach is developed in proportion to the quantity of sand eaten, and attributes to it the function of forcing the indigestible matter along the intestine. This it certainly does in Onchidella: when matter is to be passed from the stomach the gizzard drives its own contents forward, and since at the same time the initial chamber of the stomach contracts, the only available outlet is dorsal, into the terminal chamber, and thence to the intestine. If an animal be collected on its return from a meal and dissected about four hours later, food remains are massed in the intestine, although the crop and stomach are still amply distended. Frequently the animal takes in more food than the digestive system can cope with, and the quantity of undigested material in faeces which are discharged within a few hours after a meal is greater than that contained in later faecal masses. The pellets are rod-shaped and may be a centimetre or more in length. The sand grains, detritus, algal filaments and diatom cases, of which each is composed, are compacted and covered by a cementing fluid. Firmly attached to each pellet is a longitudinal beaded strand of excretory matter from the digestive gland, and directly opposite this is a shallow longitudinal groove-the impression of the typhlosole. The excreta from the digestive gland are moulded into characteristic form by the caecum, in which the longitudinal folds from the anterior liver ducts terminate. The flow of waste matter passing along the folds feeds the caecum, and when this is full its contents are moulded by its muscles, and cemented, by the viscid fluid from its walls, into a compact oval mass which is then expelled. A succession of pellets is thus formed connected end to end, and plastered against the flow of faecal matter from the stomach, to which it firmly adheres. This function of consolidating and moulding the faecal matter from the digestive gland is also attributed to the caecum of Aplysia (Howells, 1942). The small quantity of waste from the posterior liver duct is voided with the food remains from the stomach. The excretory phase of the digestive gland, which follows one of absorption, involves the digestive and excretory cells. If animals are injected with soluble iron saccharate, the iron is taken up by the three different types of cells in the gland, though most active absorption occurs in the crypts, where it either forms small spherules in the young excretory cells or is added to the brown spherules already present in the older ones. In the lime cells it appears as minute masses in the dense cytoplasm between the calcium spherules. Its ultimate fate has not been traced. Small quantities of iron are taken up by the digestive cells and accumulate with the food remains in the basal vacuoles; with these they are expelled from the distal ends of the cells and passed from the gland in the faecal stream. At the same time the oldest excretory cells, which are filled with brown spherules or in which the spherules have fused into one large clump, leave the epithelium. It would appear that the function of these cells is to take up waste matter from the blood and build it up into concentrated masses which accumulate until the cell becomes effete. A similar 
function has been suggested for cells in the digestive gland epithelium of tectibranchs (Fretter, 1939).

The passage through the intestine is lubricated by mucous secretion from the epithelium. The muscles of the tube compress the faecal matter and fashion it into a smooth rod, and the fluid from the club-shaped gland cells binds the particles together. Since the excretory matter from the digestive gland is directly opposite the impression made by the typhlosole, it is attractive to imagine that this structure exerts a pressure which helps the excretory matter to adhere to the faecal rod. During defaecation variable lengths of the rod are voided; the greater length of the intestine may be emptied at one time.

\section{RESPIRATION}

One of the most interesting features of the Onchidiidae is the presence of a lung which opens by a small pneumostome (Fig. I A, $p$ ) at the posterior end of the body, slightly to the right of the mid-line and behind the openings of the anus and vagina $(f e)$. Owing to an inadequate knowledge of its anatomy and histology the lung has been the subject of much controversy in times past: Joyeux-Laffuie (I882) and von Jhering (1877) maintain that it is a kidney which has to some extent taken over a respiratory function, whilst Semper (1876-7) and Bergh (I885), on the contrary, state that it is primarily a respiratory organ and quite distinct from the kidney, although they maintain that the two open into one another. According to Plate (1893) it is a reduced mantle cavity which has no connexion whatsoever with the kidney, since the latter discharges through the ureter into the rectum. Von Wissel (I898) accepts this interpretation, though Haller (I894) opposes it.

When an Onchidella moves actively over the rocks which are uncovered by the tide, the posterior tip of the mantle is raised to expose the pulmonary aperture. This is widely open and may remain so for some minutes. The opening leads through a short duct to a spacious cavity which, in sections, can be traced forwards on either side of the median body cavity as branching diverticula; these extend to the level of the posterior end of the heart. The lung is thus $U$-shaped and it follows the course of the kidney with which it is closely associated. The kidney, however, extends farther forwards than the lung: its right limb spreads around the median wall of the pericardium, and under the ventral wall, as far as the anterior tip of the heart. The renopericardial duct opens into the posterior end of the pericardial cavity. The left limb is less developed than this, but passes forward to about the same level. The U-shaped part of the haemocoel, in which lie the kidney and (on the right side) the heart, is separated from the general body cavity by a muscular diaphragm. This is incomplete anteriorly on the right side, so that the lateral and median haemocoelic spaces communicate by a wide opening, and through this passes the anterior aorta. Branching diverticula of the lung penetrate between the lobes of the kidney and push into the tissues of the mantle, so that they come into intimate contact with the blood spaces. 
The lips of the pneumostome are lined by a coiumnar ciliated epithelium which is surrounded by subepithelial mucous cells; the cilia beat out of the lung cavity and guard against the entry of small particles. A section through the delicate respiratory tissue of the lung is shown in Fig. 3 A. A thin outer sheet of squamous cells (os) lines the cavity, and a corresponding inner layer $(i s)$, which rests upon the tissues of the mantle $(\mathrm{tm})$ or the muscles surrounding the kidney tubules $(m)$, runs parallel with it, the two being

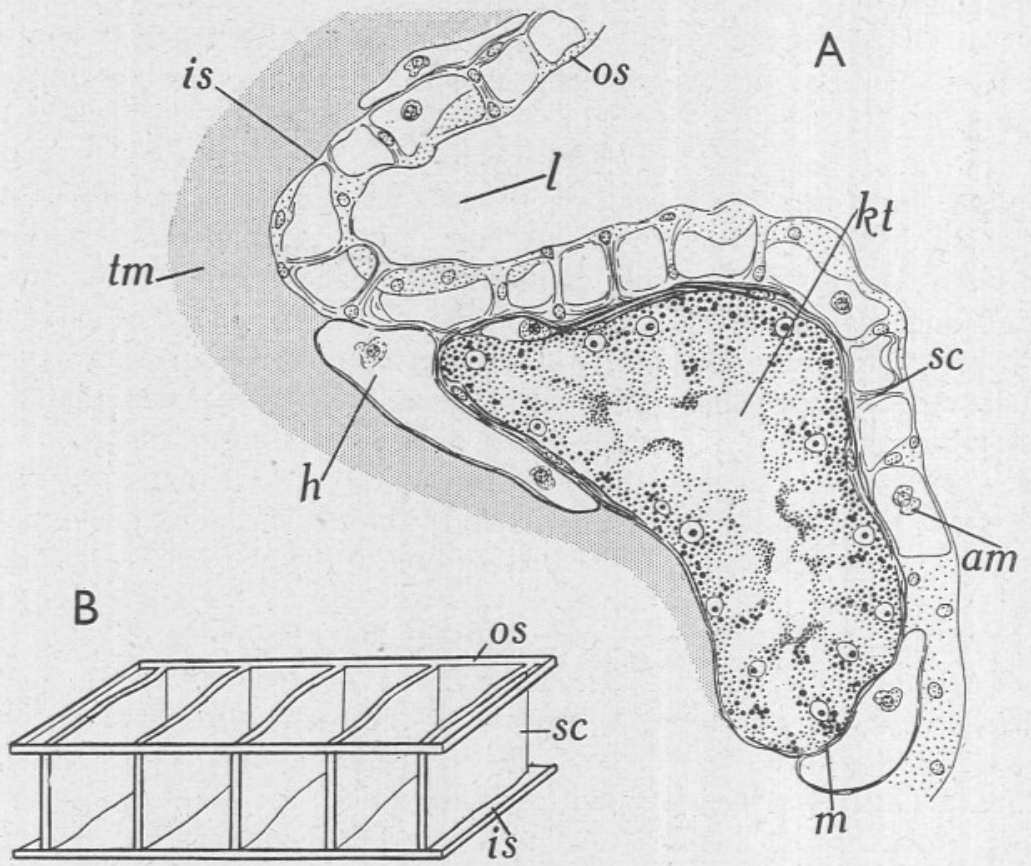

Fig. 3. A. Transverse section through wall of lung, underlying kidney tubule, mantle and associated blood spaces: $\times 400$. B. Diagram to show arrangement of blood channels in wall of lung: $\times$ about 580 . am, amoebocyte in blood channel; $h$, haemocoelic space; $i s$, inner sheet of squamous epithelium; $k t$, lumen of kidney tubule; $l$, lumen of lung; $m$, muscles surrounding kidney tubule; os, outer sheet of squamous epithelium; $s c$, squamous cells subdividing space between is and $o s$; $t m$, tissues of mantle.

separated in most places by a series of channels formed by cells of similar histological character running at right angles to the two layers $(s c)$. Blood from the surrounding haemocoelic spaces $(h)$ runs through the network of channels, and is thus separated from the lung cavity only by the rather structureless and lightly staining outer sheet of squamous epithelium. Here and there a mucous cell pours its secretion on to the respiratory surface. Should the mollusc be immersed in water the pulmonary opening closes immediately, and, since the cavity decreases in size with the contraction of the muscles of the mantle, air escapes through it. The diaphragm and muscles 
surrounding the kidney tubules may also be concerned with the ordinary respiratory movements. Normally the animal has settled in its crevice by the time of the rising tide, and the aperture has closed and remains so until the next period of activity. In the sluggish interlude pallial respiration is adequate.

The surface of the mantle is papillated and when exposed to the air is moistened by the secretion of pallial glands: these are unicellular and are grouped in clusters between the cuticularized epithelial cells. If the mollusc be removed from water and the dorsal surface thoroughly dried, it is covered, within a few minutes, by fluid from the glands. Along each side of the mantle project a number of marginal papillae (Fig. I A, $m p$ ) which are larger than the rest and equidistantly placed. Each bears at its apex a small pore through which, when the animal is irritated, a spirally coiled stream of white secretion is discharged. The secretion is produced by a large flask-shaped multicellular gland, which is embedded in the thickness of the mantle at the base of the papilla (Fig. 6C, $m g$ ); it is squeezed from the various types of cells sharing in its composition, and forced through the long straight duct, by a surrounding muscle layer of considerable thickness. The histology of the glands appears to be similar to that of Oncidiella (=Onchidella) marginata and O. juan-fernandeziana (von Wissel, I898). The marginal or peripheral glands in Onchidium are referred to by Arey \& Crozier (I92I) as repugnatorial glands, and it is stated that sea anemones and crabs refuse to eat food tainted with the secretion.

In O. verruculatum (Hirasaka, I922) the dorsal papillae of the anterior twothirds of the mantle bear eyes, and those of the posterior third are produced into tree-like gills. Neither of these are developed in Onchidella, though the respiratory importance of the mantle is very considerable owing to the interlacing network of blood capillaries below the epithelium. The mollusc can live under water for long periods, relying entirely on pallial respiration; its activities, however, are then reduced. It can also rely on this alone when it is inactive at low tide. Pulmonary respiration supplements pallial respiration when the respiratory requirements of the animal are increased during activity out of water, but experiments show that either is sufficient by itself to keep the animal alive for at least a week. If the dorsal surface be vaselined and the animal placed in a humid atmosphere, the pulmonary aperture is opened and the lung is used continuously; frequently the edges of the mantle are upturned as if in an attempt to increase the respiratory area. The behaviour appears to be more normal when the pneumostome is blocked with vaseline, and specimens thus treated may occasionally wander about, though only over a limited distance. Should both mantle and lung be thrown out of action death follows in a few hours.

Although Onchidella is on the whole restricted to damp situations in which the humidity conditions approach those of saturation, the fact that in midAugust it can be seen to leave the shady rock and travel over sunny surfaces, 
shows that it can survive, at least for a short time, in lower humidities. In order to investigate the degree of desiccation which the animal can resist specimens were subjected to relative humidities of less than $100 \%$. The required humidities were obtained by placing dishes with sulphuric acidwater mixtures of known specific gravity in the bottom of large jam jars, and placing above the open dishes a platform of perforated zinc. Eight animals were introduced into each jar and a glass plate was sealed to the opening with vaseline. The animals appeared to show a distinct negative geotaxy: they invariably attached themselves to the glass plate or to the sides of the jar, and rarely descended as far as the zinc platform. Edney paper hygrometers were used for measuring the humidity. The results are contained in the following table:

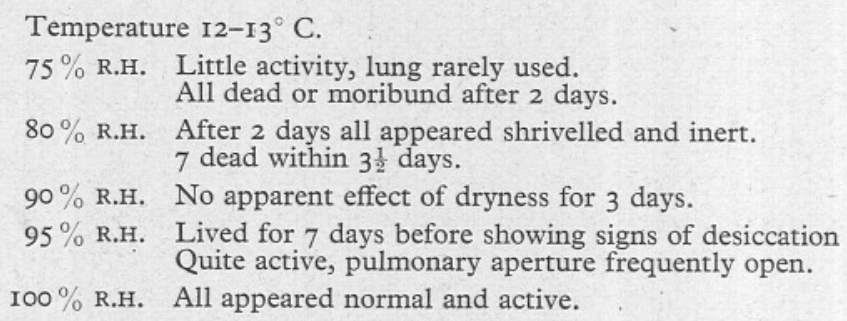

When introduced into a humidity gradient ranging from 75 to $95 \%$ R.H. the animals made no attempt to aggregate in regions of optimum humiditythey are completely akinetic.

\section{The Reproductive System}

The account of the reproductive system given by Joyeux-Laffuie (I882) includes little histology, and important points in the anatomy are overlooked. Plate's (1893) and von Wissel's (I898) descriptions of other members of the Onchidiidae indicate that throughout the family the gross structure of the reproductive organs is remarkably uniform, though in no case is the detailed course of the male and female ducts elucidated, and such essential structures as the fertilization chamber, with its associated receptaculum seminis, and the large prostate gland on the male duct have not previously been described.

In Onchidella celtica the yellowish brown hermaphrodite gland, which lies in the posterior part of the body cavity, is divided into two main lobes, each acinous in structure. Young individuals are protandrous, but later both types of sex cells are found in all acini of the gland, with the spermatozoa always far more numerous than the ova. The ducts through which the genital products pass to the hermaphrodite duct are ciliated. The proximal part of the hermaphrodite duct acts as a vesicula seminalis; it is coiled in a close spiral which passes forwards for a short distance on the left side of the haemocoel. The epithelium is columnar and ciliated, save for a longitudinal strip of gland cells, which, in animals dissected during late summer and autumn, appears as a deep brown streak; in spring there is little or no external 
indication of the glandular area. The pigmentation is due to brown refringent granules in the highly vacuolated protoplasm of the gland cells. The free ends of the cells may be irregular in outline and here the protoplasm is more dense than elsewhere. Sperm are entrapped by the dense protoplasm and engulfed; they have never been seen in the deeper layers of the cells, so the granules which accumulate there are probably products of sperm digestion. A similar activity on the part of the corresponding region of the male duct has been described by Linke (I933) in three species of Littorina, and also in Ocenebra erinacea, Nucella lapillus, Nassarius reticulatus and Buccinum undatum (Fretter, I94I). The distal part of the hermaphrodite duct is closed off from the vesicula seminalis by a sphincter, and turns abruptly to the right to lead straight back towards the hermaphrodite gland. At the end of this part of its course it winds into a knotted mass of fine coils, which are not visible superficially, since all are bound together by connective tissue and covered externally by a connective tissue sheet supplied with circular muscles (Fig. 4, chd). The fine coils lead anteriorly and open into a wider region of the duct $(h d)$ which runs forwards and ventrally, through the flocculent mass of the albumen gland, to a small fertilization chamber $(f c)$. The opening into this wider region lies at the base of a shallow longitudinal groove which leads posteriorly to the opening of a small caecum (c), and continues along the duct anteriorly for a short distance. The caecum has a narrow neck and broadens at its blind end; the epithelium, which is covered by extremely long cilia, is thrown into a few deep folds, and these subdivide the lumen. It is referred to as the vesicula seminalis by Joyeux-Laffuie (I882), though he failed to realize that the proximal part of the male duct acted as such, and actually only on one occasion have a few sperm been found in the pouch. Its size appears to vary throughout the Onchidiidae: in the genus Onchidella it would appear to be generally small since von Wissel (I898) describes it as a small diverticulum, about $0.5 \mathrm{~mm}$. in length, in Oncidiella (=Onchidella) marginata and O.juan-fernandeziana and alleges that it is absent in O. coquimbensis. In the genus Onchidium, however, it is considerably larger and is figured by Plate (I893) in $O$. verruculatum and $O$. nigrum of such a size that the name vesicula seminalis is well merited. Hence it would appear that in the genus Onchidella it is an incipient or vestigial structure. The distal part of the hermaphrodite duct is lined throughout by a ciliated epithelium, with circular muscles beneath the basement membrane and longitudinal fibres outside. The cilia are long in the coiled region $(c h d)$, but in the caecum they may exceed five times the height of the cells; here, also, the muscle coat is very thick.

The ducts of subepithelial glands open between the ciliated cells which line the fertilization chamber $(f c)$. The glands are embedded in a layer of connective tissue, and their cytoplasm contains small secretion spherules which stain deeply with iron haematoxylin. A few may lie in the epithelium. The chamber receives paired ducts, one from the left and the other from the 


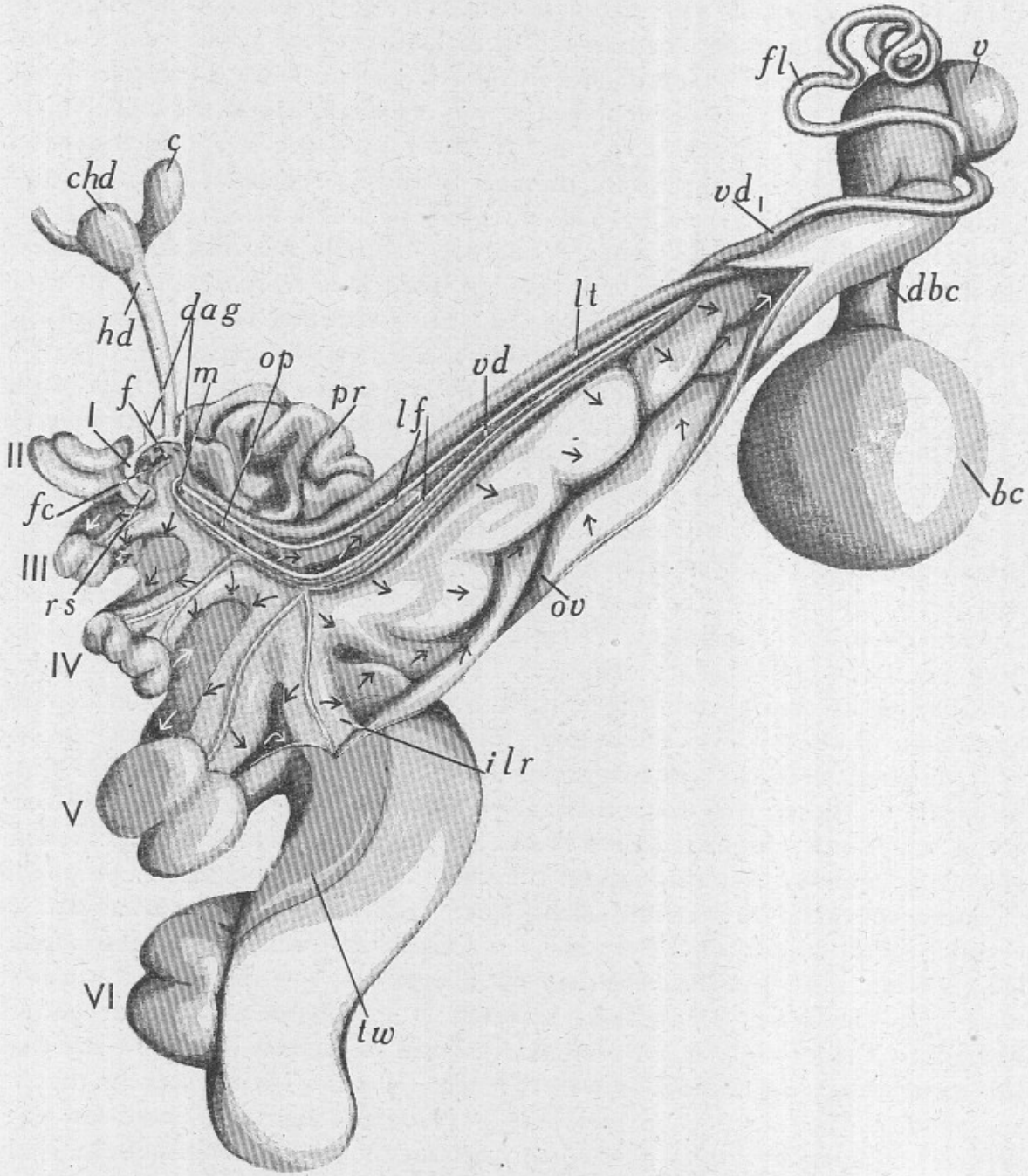

Fig. 4. The reproductive ducts: $\times 20$. The middle glandular section of the hermaphrodite duct has been slit open longitudinally and the duct uncoiled. The albumen gland has been removed. $b c$, bursa copulatrix; $c$, caecum; chd, fine coils of hermaphrodite duct covered by connective tissue; $d a g$, duct of albumen gland; $d b c$, duct of bursa copulatrix; $f$, opening of hermaphrodite duct into oviduct; $f c$, fertilization chamber; $f$, flagellum; $h d$, hermaphrodite duct; ilr, internal longitudinal ridge of oviducal pouch; $l f$, longitudinal flange; $l t$, longitudinal tract leading from receptaculum seminis to duct of bursa; $m$, opening of hermaphrodite duct into vas deferens; ov, oviduct; $o p$, opening of prostate; $p r$, prostate; $r s$, receptaculum seminis; $t w$, thin wall of spiral caecum; $v$, vagina; $v d$, vas deferens; $v d_{1}$, non-glandular part of vas deferens; I-VI, oviducal pouches. 
right lobe of the albumen gland $(d a g)$. This is orange in colour and the two lobes are bound together by connective tissue and lie dorsally over the oviduct and vas deferens. Their ducts are short and ciliated, and each is formed by the union of smaller collecting ducts. The secreting cells, all of a single type, are grouped in small clusters which are bound to one another by a thin layer of connective tissue. The cytoplasm is filled with yellow, granular spherules and these stain an intense blue with azan, are not affected by mucicarmine, and stain rather deeply with iron haematoxylin.

The lumen of the hermaphrodite duct, on approaching the fertilization chamber, appears as a longitudinal slit, which becomes divided into left and right channels by a slight constriction. The duct runs beneath the chamber for a short distance and the left channel, which is the larger of the two, opens laterally into it $(f)$; the opening is opposite those of the albumen ducts. Through this passage the eggs are conducted to the oviduct (ov). The right channel, on the other hand, is the beginning of the vas deferens $(m)$, but, although here the male and female passages are separated from one another, during the next part of their course the separation is merely functional. The vas deferens $(v d)$ runs back, accompanied by the female part of the duct (ov), towards the posterior end of the body, lying to the right of the hermaphrodite duct. It is a deep gulley, V-shaped in transverse section and surrounded by a thick layer of subepithelial glands. During the proximal part of its course the apex of the $V$ is directed ventrally, and the oviduct, a similar longitudinal glandular groove, lies on its left, the two passages having a common dorsal wall. A longitudinal ciliated flange ( $l f$ ) on each side of the mouth of that gulley which acts as vas deferens, closes it off from the oviduct. On the dorsal wall of the female channel, above the flanges guarding the male section, is a longitudinal ciliated tract (lt) leading upwards to the receptaculum seminis $(r s)$ and downwards to the duct of the bursa copulatrix $(d b c)$. Near the origin of the male duct lies the opening $(o p)$ of the large prostate gland $(p r)$. This is a sac-like outgrowth of the glandular walls of the vas deferens, and its walls are deeply folded. The gland cells here and in the vas deferens are grouped in clusters, bound together by connective tissue, and their long ducts open between ciliated cells which direct the secretion along the male duct. The gland cells have large spherical nuclei with very prominent nucleoli and the secretion spherules which fill the vacuolated cytoplasm stain with iron haematoxylin; those in the ducts take the stain most readily. After azan the spherules are red and the cytoplasm purple. In the vas deferens muscle fibres, circular and oblique in direction, pass through the connective tissue between the glands, and also form an external layer which is concentrated on the right side of the gulley and around the dorsal wall.

The common genital duct, with its parallel male and female divisions, passes back through the haemocoel and becomes twisted in such a way that the vas deferens appears to curve around the right side of the oviduct and then to pass across its dorsal surface to the left side. The twist causes the 
openings of the two channels to face not dorsally, as in the anterior region, but to the left. At this point the vas deferens becomes completely separated from the oviduct, and for the rest of its course it is a narrow, ciliated and non-glandular duct with muscular walls $\left(v d_{1}\right)$. It passes beneath the female duct to the origin of the external ciliated groove (Fig. I A, cg). This leads from the female aperture $(f e)$, and passes around the right side of the body near the junction of the foot and body wall, to the pedal mucous gland. The vas deferens enters the muscles above the groove and runs parallel with it. Just behind the male opening $(m a)$, which is situated a short distance behind the right tentacle, it returns to the haemocoel and runs back in a sinuous course to the base of the retracted penis. During the final part of its course mucous cells, which are wedged between the fibres of the thick coat of circular muscles, open into the narrow tube; the penis sheath is also lubricated by subepithelial mucous and mucoid glands. The retractor muscle of the penis is very long, and from the base of the copulatory organ it runs straight back in a ventral position to its origin on the dorsal surface of the foot beneath the bursa copulatrix.

The oviduct is complicated in its anterior part by the development of six pouches which are outgrowths of the glandular wall (Fig. 4, I-VI), and which serve to increase the distance through which the eggs must travel on their way to the female aperture. The first of these pouches is very small; it overhangs the fertilization chamber and acts as a receptaculum seminis $(r s)$. The walls at the blind end are an opaque white, and resemble in histological detail the glandular walls of the fertilization chamber. In all other parts the glandular area of the oviduct is yellow. The remaining five pouches are of increasing size, with the sixth very much broader and longer than the othersit is coiled in a spiral and may exceed the whole of the rest of the oviduct in length. The four pouches anterior to it (nos. II-V) lie over the proximal end of the female channel. In other members of the Onchidiidae more than one spirally wound outgrowth from the genital duct has been described: two are figured by Plate (1893) in Onchidium verruculatum and three in O. nigrum, and these extra spirals appear to correspond with some of the smaller pouches in Onchidella celtica.

The wall of the oviduct is composed of columnar ciliated epithelium resting upon a thick and compact layer of gland cells which pour their secretion into the lumen of the duct. Along each pouch the epithelium is folded to give an internal longitudinal ridge (ilr). In the long spiral caecum (no. VI) that part of the wall directly opposite the ridge is thin with few subepithelial glands $(t w)$. The base of the first pouch and the second, into which are directed the fertilized eggs with their coat of albumen, produce a mucous secretion. In the two succeeding pouches (nos. III and IV) the secretion is similar, but stains less easil,... ith mucicarmine and slightly with iron haematoxylin. In the last two pouches (nos. V and VI), the largest of the series, the same two kinds of cell occur, and also a third type of gland which 
gradually replaces the other two and is especially numerous in the spiral pouch. The protoplasm is vacuolated and the majority of the spherules contained in the vacuoles are untouched by mucicarmine, stain rather deeply with iron haematoxylin and deep blue with azan. At certain centres of activity within each cell clumps of mucoid spherules occur, though they are not found in the ducts of the glands, and the final secretion is untouched by stains which are considered to be specific for mucus. The subepithelial cells of the main channel of the oviduct, which passes from the spiral caecum towards the female aperture, are mucoid glands, and in the connective tissue which binds them together in groups run a few circular and oblique muscle fibres. Such fibres enable the oviduct to be closed off from the rest of the genital duct. The gland cells decrease in number after the separation of the male and female channels, and the oviduct becomes a ciliated tube which is surrounded by a very thick coat of muscles. It curves ventrally and then describes a slight dorsal loop which receives on its dorsal wall the duct of the bursa copulatrix $(d b c)$. The longitudinal ciliated tract $(l t)$, which arises anteriorly near the receptaculum seminis and runs back between the original dorsal wall of the genital duct and the ciliated folds over the vas deferens, curves to the right with the twisting of the common genital duct, and, after the separation of the vas deferens, runs along the dorsal wall of the ventral curve of the oviduct to the opening of the duct from the bursa. The bursa $(b c)$ lies anteriorly beneath the common genital duct; it is a large spherical vesicle and on dissection appears strawberry-pink in colour and flecked with a white calcareous deposit. It is lined by tall glandular cells with oval, nucleolated nuclei lying in the lower half of the cytoplasm. This is vacuolated throughout and the small secretion spherules contained in the vacuoles are dissolved on fixation. The free ends of the cells often have an irregular outline due to the discharging of the secretion. Beneath the basement membrane of the epithelium are a few circular muscles, and outside these the connective tissue contains blood spaces surrounded by large cells which are laden with calcium granules. The lumen of the bursa is invariably filled with a reddish brown fluid and in this may be found irregularly shaped refringent masses of a similar colour. During spring and summer there are clumps of spermatozoa, and a few living sperm have been seen there in December. The fluid is derived from the prostate secretion and from the wall of the vesicle, though neither of these secretions are so deeply pigmented when first liberated. The duct from the bursa $(d b c)$ is lined by tall, columnar, ciliated cells and surrounded by a thick coat of circular muscles, with which are interspersed longitudinal fibres. It runs beneath the posterior end of the oviduct, and around its right side, to open at a point which marks the beginning of the vagina $(v)$. The vagina, a very muscular tube, passes ventrally to the female aperture which lies to the right of the anus. A long flagellum $(f)$, with yellow glandular walls, coils over its dorsal surface and opens into it ventrally by a short duct. The opening is just posterior to the opening of the duct from the 
bursa. Joyeux-Laffuie (I882) refers to the flagellum as the caecal appendage or mucous gland, though the latter name is misleading since the secretion is not of a mucous nature. A fine canal runs through the flagellum and is lined by gland cells and ciliated cells; in the duct a columnar ciliated epithelium occurs and there are no gland cells. The secreting cells, which have basal nuclei, contain spherules of varying sizes clustered at the distal end of the cytoplasm. The ciliated cells are constricted by the gland cells and the nuclei are elongated and situated in the-mid-region of the cells. A coat of circular muscles underlies the basement membrane and forms a sphincter around the duct. In the vagina the epithelium is columnar and ciliated, and the connective tissue below is ramified by radial, circular and longitudinal fibres, between which are mucous cells; externally a thick and compact coat of circular muscles forms a sphincter.

The vagina opens to the right and slightly in front of the so-called anus (Fig. I A, $f e, m c o$ ). A groove connects the two apertures and the lips of the groove run into those of the vaginal aperture, on the one hand, and those of the anus on the other. The ciliated groove $(\mathrm{cg})$, arising at the female aperture, is lined by a columnar epithelium with short cilia. The epithelium is ridged longitudinally, both because of the fact that the supporting connective tissue varies in thickness and because the cells are of unequal height; the surface is lubricated by a few subepithelial mucous glands. A muscle coat of considerable thickness lies in the connective tissue, the fibres being mainly circular in direction, and the groove can be deepened so that the longitudinal ridges are obliterated, and the two lips then approximate to form a virtual tube. Although several attempts have been made to study the ciliary currents on the walls, only on one occasion was movement observed-this was very slight and directed anteriorly. The groove leads to the pedal mucous gland, which lies above the anterior tip of the foot and is a deep pouch with an extensive transverse opening $(o)$. At its inner end the pouch is divided into two by a horizontal muscular partition, and the ciliated groove, which passes into the gland on the right side, runs straight back and ends in the shallower, dorsal chamber $(d c)$. A cuticularized epithelium lines the walls of the undivided part of the gland, and the whole dorsal chamber except for the right wall on which the ciliated groove runs. The cuticle is pierced by the ducts of subepithelial gland cells. The dorsal chamber is very muscular, most of the muscles being circular, a few longitudinal or oblique. The ventral chamber $(v c)$ is glandular, and the secreting cells, which are subepithelial, surround the ventral and lateral walls, opening to the surface between ciliated cells, whilst the dorsal wall is cuticularized. The secreting cells are for the most part mucous and mucoid glands, the former being especially numerous laterally. In the undivided part of the pedal gland the secreting cells decrease in number. In addition to mucous and mucoid cells two other types of secreting cells are present, and a few of these spread into the ventral chamber: in one, which is ubiquitous in the tissues of the foot, and is also found around 
the ciliated groove and the dorsal chamber of the pedal gland, the secretion is in the form of large protein spherules; in the other the cytoplasm is homogeneous and granular, but contains one or two large vacuoles with no apparent contents.

Egg masses of Onchidella celtica are found in the crevices inhabited by the adults and several may occur together. Each mass, which is laid by one individual and contains from sixty to over a hundred eggs, is somewhat flattened and of an irregular outline, measuring about a centimetre in diameter. It is firmly cemented to the rock, in most cases to the roof of the slanting crevice, and consists of the irregular coilings of a long tubular capsule which is embedded in jelly, and which is expanded at regular intervals by the eggs. Each egg lies at the centre of an oval mass of transparent albumen, and that in its turn is covered by the capsule wall. Between one egg and the next the capsule narrows to a fine strand. The capsule wall is made up of three distinct layers: an inner mucoid coat and middle and outer layers which, though thin, are very tough, the former staining lightly with iron haematoxylin and the latter deeply. The strand between any two eggs has a similar structure: in the centre is the mucoid layer, enclosing perhaps a streak of albumen, but the two outer layers are thicker than elsewhere since they are not distended, and here they appear to be made up of concentric sheets of a similar secretion which, in the middle layer, are separated by mucoid fluid.

Joyeux-Laffuie (I882) states that fertilization is reciprocal and Hoffmann (I929) figures the position of two copulating individuals in which the right borders of the mantles are in contact, the anterior ends pointing in opposite directions, and in each the penis is protruded from beneath the anterior edge of the mantle on the right side and thrust into the female aperture of the other. Sperm, embedded in prostatic secretion, are deposited in the bursa copulatrix, and in mature individuals collected during early summer they are present there in large numbers. Joyeux-Laffuie (I882) assumes that the eggs are both fertilized and encapsulated in the vagina, but a more detailed knowledge of the genital duct shows that this cannot be the case. From the bursa (Fig. 4, bc) the sperm make their way to the receptaculum seminis ( $r s$ ) via the longitudinal groove $(l t)$ which connects these two regions of the female tract, and there they await the discharge of the eggs into the fertilization chamber $(f c)$. It is not known how soon after copulation the formation of egg capsules may begin.

When the eggs are passed down the hermaphrodite duct the proximal end of the vas deferens is contracted and they proceed along the wider female channel to the fertilization chamber. This is distended with secretion from the albumen gland and, one by one, the eggs are discharged into the secretion and are also fertilized. The stream of eggs and albumen now starts on the cirçuitous journey down the oviduct entering each of the six pouches (I-VI) in turn and being directed through these by the ciliary currents on their walls. Meanwhile the encasing capsule wall is secreted. The actual secretion of this 
wall has not been observed, though the part played by the various types of glands may be conjectured.

Prior to the entry of the fertilized eggs the glands of the oviduct discharge their secretion. In the first two diverticula of the duct this is mucous, and together with the mucoid secretion from the two succeeding diverticula it supplies the material for the manufacture of the inner layer of the capsule wall. The two outer layers are produced by the fifth and sixth diverticula, the largest of the series, with the sixth providing the most extensive glandular area of the whole oviduct. In these diverticula the mucous and mucoid cells are gradually replaced by glands which furnish a secretion with the same staining properties as the outer layer of the egg capsule; in no other area of the oviduct do such glands occur. The outer layer of the capsule wall is composed entirely of this secretion, whilst the middle one is composite, being an admixture of the inner and outer layers. In the posterior part of the oviduct the subepithelial glands lubricate the passage for the stream of eggs and add to it a thin mucoid covering. The exact locus at which the whole mass is acted upon so that it acquires its moniliform appearance is uncertain. It may be in the muscular vagina, or even outside the female duct if the process is purely physical.

The contents of the oviduct are presumably discharged into the ciliated groove. The cilia may at such a time become more active and combine with the muscles in effecting the passage of eggs along the groove and into the dorsal chamber of the pedal mucous gland. Since this chamber is very muscular the egg string may be moulded here. It seems reasonable to assume that the secretion in which they are embedded, and which cements them to the substrate, is poured from the glandular walls of the pedal gland, for this secretion has the same texture and staining properties as that supplied by the gland.

\section{EMBRYOLOGY}

The newly laid capsules of Onchidella celtica may be collected in July, August and the beginning of September; it is doubtful whether any are produced later. Within the capsule the embryo passes through a prosobranch veliger stage, followed by a post-veliger which shows gradual detorsion and a recession of the visceral hump, so that before hatching the appearance of the adult is assumed. In December and January empty capsules have been found in the rock crevices, as well as capsules containing veligers and post-veligers. The development of these was presumably retarded by the low temperature of the winter months, which may also account for the number of malformed individuals among them. Joyeux-Laffuie (1882) alleges that embryos kept in the laboratory, if not carefully attended, take on abnormal shapes, such abnormalities occurring more frequently in Onchidella than in other gastropods. It is the earliest post-veliger stages of detorsion which are most frequently malformed and among which there is the highest mortality. Spawn has been obtained from animals in captivity and from this normal embryos developed. 
In such egg masses laid during the first week in July the veligers were fully formed in seventeen days, and about a month later their embryonic development was near completion-they appeared as miniatures of the adult. They hatched a week or so after. Only those points in the development which help to elucidate the adult structure are considered here, and the stages leading up to the veliger are completely omitted.

\section{The Veliger}

The veliger measures about $0.3 \mathrm{~mm}$. in length, and by means of the large bilobed velum (Fig. $5 \mathrm{~A}, v_{1}$ ) it swims in the surrounding albumen. A pair of eyes (e) is developed, each situated on a slight protuberance which represents the rudiment of an adult tentacle. The foot $(f)$ has a triangular sole and bears a large operculum $(o p)$ which was not observed by Joyeux-Laffuie (I882); near the broad base are embedded two otocysts (o), symmetrically placed, one on each side. At the anterior end of the foot the pedal mucous gland is present. The visceral hump is covered by a thin transparent shell $(s h)$, which shows an endogastric coiling through about $180^{\circ}$, and on the right side is the mantle cavity (Fig. $6 \mathrm{~A}, m c$ ). This communicates with the exterior by a wide opening and at its extreme inner end is the anus. Projecting into the mantle cavity above the anus is a transitory organ, the larval kidney (Fig. 5A, $l k$ ), which corresponds in structure and position with what Mazzarelli (I906) calls the secondary kidney of the opisthobranchs; JoyeuxLaffuie (I882) mistakes it for the hermaphrodite gland. Sections show that it comprises three cells (Fig. 6A, $l k$ ), one much larger than the others. They are held together by a fine layer of connective tissue and their bases are directed upwards towards the dorsal surface. The nuclei are large and deeply staining, each with two nucleoli, and the cytoplasm is highly vacuolated; in the vacuoles small granules occur. It is uncertain whether this kidney communicates with the exterior: the suggestion of a minute opening has sometimes been seen, and it may be that the aperture is only visible when a drop of excretory matter is expelled. The rudiments of the definitive kidney of the mollusc can be found in a somewhat undifferentiated mass of cells (Figs. $5 \mathrm{~A}$ and $6 \mathrm{~A}, r d k$ ) which lies above the larval kidney and between it and the pericardium.

Behind the velum and on either side of the oesophagus, in the young veliger, is a small opaque rounded body with green-brown granules, the so-called larval organ of Joyeux-Laffuie (I882). These are also transitory structures which cannot be traced in later stages, and appear to be homologous with the primary or cephalic kidneys of opisthobranchs and other pulmonates (Mazzarelli, I906).

The mouth, which is median and situated beneath the velum, is surrounded by long cilia. It leads into the buccal cavity, a ventral diverticulum from which forms the rudiment of the odontophore. The oesophagus (Fig. 5 A,oe) passes through the nerve ring $(g)$, where the ganglia are concentrated as in 
Fig. 5.

A. Veliger from the right side: $\times 170$

B. Early post-veliger $\times$ I5O.

C. Embryo at middetorsion: $\times 120$

D. Embryo near completion of detorsion: $\times$ IIO.

$a$, auricle; $c$, cerebral ganglion; $c v$, cardiac vesicle; $d k$, definitive kidney; $e$, eye; $f$, foot $g$, ganglia of nerve ring; $i$, intestine; $l$, left lobe of digestive gland; $l k$, larval kidney or secondary kidney; $m$, mantle; $m g$, marginal gland; $o$, otocyst; od, odontophore; oe, oesophagus; omc, opening of mantle cavity; op, operculum; $p$, pedal ganglion; $p m$, pigment of mantle; $r$, right lobe of digestive gland; $r d k$, rudiments of definitive kidney; rlk, remains of larval kidney; sh, shell; sl, sensory lobe; st, stomach; $v$, ventricle; $v_{1}$, velum; $v r$, velar retractor muscle.
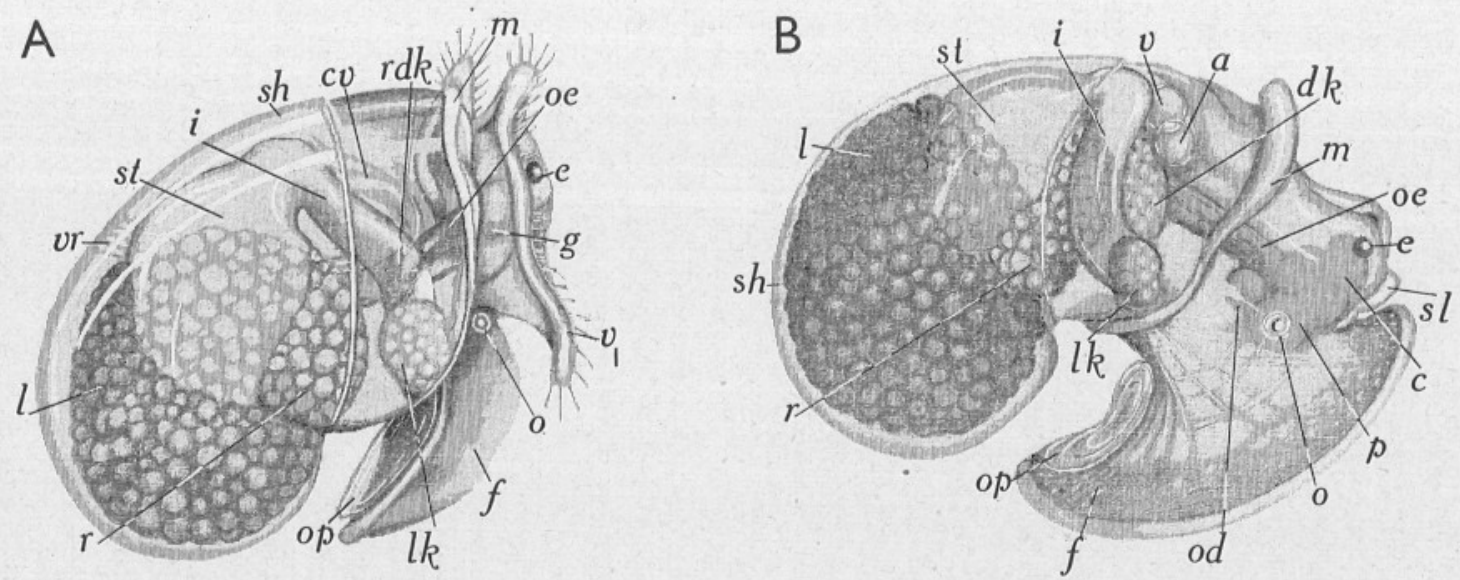

C
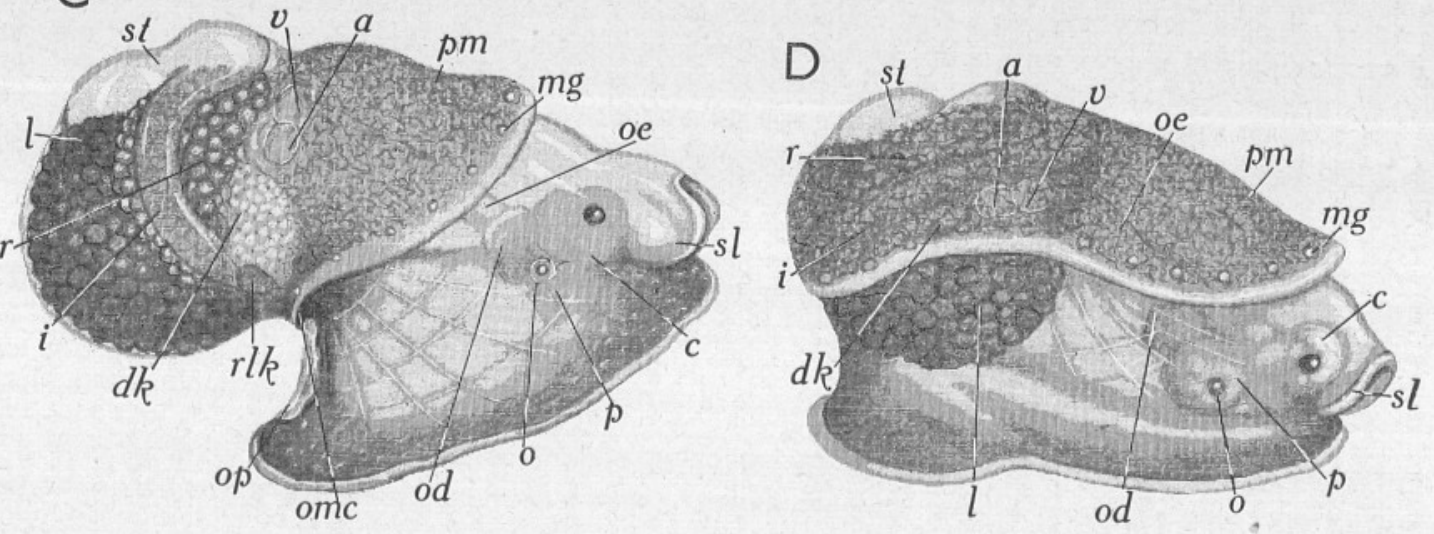
the adult, and runs straight back to the stomach (st), into which it opens ventrally on the right side. The stomach and digestive gland comprise the visceral mass, the latter not yet constricted from the stomach. The gland is divided into two unequal lobes-a larger left one (Figs. $5 \mathrm{~A}$ and $6 \mathrm{~A}, l$ ) which occupies the whole left wall and spreads posteriorly and ventrally around the gastric sac, and a smaller right lobe $(r)$ which is restricted to an anterior strip on the right wall. The intestine (Fig. $5 \mathrm{~A}, i$ ) leaves the stomach dorsally, on the right side, above the point of entry of the oesophagus, and passes below the dorsal integument to the anus. The heart is dorsal and towards the right side: in the early veliger it is indicated only by a vesicle (Figs. $5 \mathrm{~A}$ and $6 \mathrm{~A}, \mathrm{cv}$ ) which contracts at rather irregular intervals; but later the auricle and ventricle can be distinguished, the latter lying to the left and slightly posterior to the auricle. The velar retractor muscle (Fig. $5 \mathrm{~A}, v r$ ) is situated on the left side of the larva and is inserted anteriorly around the foregut and the posterior part of the velum. It passes back on the left side of the stomach to its posterior attachment near the median part of the shell. The velum is withdrawn into the shell when the muscle contracts-a movement which will also help the circulation of the blood.

The organization of the veliger is typically prosobranch, as is indicated by the following points: the mantle cavity lies on the right side, the rudiments of the definitive kidney are anterior to the rectum, and it is the hepatic area on the left which is enlarged.

\section{The Post-veliger}

During early post-veliger life (Fig. 5B) the foot $(f)$, now covered by ciliated epithelium except in the region of the operculum, develops a large, oval, creeping sole which enables the embryo to cling to and creep around the capsule wall, the path being lubricated by the pedal mucous gland. The otocysts (o) persist and Joyeux-Laffuie (I882) has traced them into the adult; in the later stages of development, at the time when the operculum is lost, they are far less obvious. The velum is not cast off as a whole, its ciliated covering is gradually lost and the two halves appear to be transformed into the sensory lobes which border the mouth (Figs. 5 B, C, D, sl) and have been described in the adult. The tentacles are still represented by the broad bosses with an eye situated in the middle of each. Later the shell (Fig. $5 \mathrm{~B}, s h$ ) is cast off and the velar retractor muscle lost.

When detorsion takes place it is effected slowly, and, as may be seen from Figs. 5 B, C and D, it is accompanied by an increase in the diameter of the neck region connecting the head and foot to the visceral hump, mainly in an antero-posterior direction, and also by the gradual recession of the visceral hump as the viscera come to project into this neck. While the mantle cavity migrates along the right side to a more posterior position its opening to the exterior is reduced in size; the blind end, which receives at its extremity the opening of the rectum, and is at first directed posteriorly, becomes 
ciliated. Black pigment is developed in the subepithelial tissues of the mantle (Fig. $5 \mathrm{C}, \mathrm{D}, \mathrm{pm}$ ), appearing at first around the anterior border and immediately behind the rudimentary marginal glands, which are just visible, and then extending laterally so as to reach the posterior end, leaving the visceral hump light in colour because here the mantle is thin and there is little or no subepithelial tissue. As the visceral mass is reduced in size so the mantle which covers it thickens and then becomes pigmented.

During detorsion the stomach and digestive gland rotate through approximately $90^{\circ}$, so that the right side becomes dorsal and the dorsal surface lies towards the left. It must be emphasized that this movement is not one of detorsion, but is forced upon the alimentary canal so that it can accommodate itself to changes in the disposition of viscera elsewhere, due to movements of detorsion. The left lobe of the digestive gland (Fig. $5 \mathrm{C}, \mathrm{D}, l$ ) becomes ventral and the smaller right lobe dorsal $(r)$. They have both been gradually constricted from the stomach and are now completely separated from it at the posterior end, where it forms a closed sac lined by columnar epithelium. The original left lobe opens into the stomach by an aperture occupying the greater part of the ventral wall (Fig. 6B, vo), and the original right one has a dorsal and less extensive opening into the anterior end and towards the right side $(d o)$. Each extends forwards for a short distance in front of the stomach, and the oesophagus is now directed dorsally over the broad anterior diverticulum from the ventral lobe, and opens into the stomach between this and the small anterior diverticulum from the dorsal lobe. The intestine, lined by ciliated epithelium, still arises dorsally, but on the left side (oi), a short distance behind the oesophageal opening. It passes over the oesophagus, as in the adult, to describe a slight anterior loop, and then leads back on the right side, behind the definitive kidney, to the anus (Fig. 5 C, D). During its whole course it lies dorsal to the digestive gland and at times the beating of the cilia of the epithelium and the sudden contraction of muscle cells, which are developing around the intestinal wall, can be seen through the mantle.

In the early stages of detorsion there are only two openings of the digestive gland into the stomach, one for each lobe. Later a third appears at the posterior end of the stomach. It is ventral (Fig. 6C, po) and communicates with the posterior portion of the original left liver lobe, which has become divided from the anterior part and forms the posterior liver lobe of the adult. The writer cannot agree with Joyeux-Laffuie's (I882) statement that the posterior lobe of the adult is derived from the original right: here, as in Aeolis (Fischer, I892), it is the larger left lobe which divides to give the left and posterior lobes of the adult.

By this time the cilia around the mouth have been lost and the radula is developed. As soon as the odontophore muscles are functional the tongue is, at intervals, rhythmically protruded through the mouth; at first the action is only feeble, but later the radula draws in some of the surrounding albumen 
which is used as food. The salivary glands are distinguishable in the late veliger, when they appear as clumps of mucous cells pressed against the oesophageal tube and behind the nerve ring, one clump lying against the ventral wall of the oesophagus and the other against the dorsal. With detorsion the oesophagus rotates through $90^{\circ}$ so that the ventral clump of mucous cells becomes the left salivary gland of the adult, and the dorsal group the right salivary gland.

The secondary kidney (Fig. $5 \mathrm{C}, r l k$ ) degenerates as the definitive kidney $(d k)$ is differentiated. The latter forms a rather elongated mass of cells, one end of which lies on the median side of the larval kidney and abuts on to the mantle cavity, whilst the other end is directed dorsally. The kidney is in communication with the pericardium by the renopericardial duct, which at this stage is relatively much wider and shorter than in the adult and is not ciliated. It is given off from the auricular end of the pericardium and runs towards the mantle cavity. At the point where it reaches the ventral end of the definitive kidney it opens into the primary ureter which discharges into the mantle cavity in front of and dorsal to the anus. It is thus seen that whereas in the typical mollusc the excretory tissue is developed on the walls of the original coelomoduct, connecting the pericardium and mantle cavity, in Onchidella these remain always relatively undifferentiated, and the definitive excretory cells are formed from the block of tissue lying alongside the duct. At a later stage this block of tissue cavitates and the lumen is placed in connexion with the pericardium by way of the renopericardial canal, and with the mantle cavity by means of the primary ureter. The heart is at first transverse and the auricle lies to the right of the ventricle and in front of the anterior loop of the intestine. During detorsion it moves back along the right side and the auricle comes to lie behind the ventricle (Fig. $5 \mathrm{~B}, \mathrm{D}, a, v$ ).

\section{The Embryo at the time of Hatching}

Some days before the embryo frees itself from the capsule it has attained the superficial appearance of the adult: it is oval in outline, a flat creeping foot covers the ventral surface and the pigmented mantle covers the dorsal. All traces of the projecting visceral hump have disappeared. The tentacles are still broad lobes bearing the eyes and they are invaginable. The head can be withdrawn into the shelter of the mantle which has grown down over it, and also overhangs the foot, so that the side walls of the body (Hoffmann, I929) are hidden. As the mantle edge grows downwards these side walls rotate from their original vertical position to one where they slope upwards and outwards at an angle of $45^{\circ}$. The edge of the mantle turns under and inwards to join them and the two surfaces lie in the same plane. The marginal glands (Fig. $5 \mathrm{D}, \mathrm{mg}$ ), developed in the tissues of the thickened edge of the mantle, open on to the dorsal surface; as yet no papillae are developed. The opening of the mantle cavity (Fig. $6 \mathrm{C}$, omc) has the appearance of a small 
A
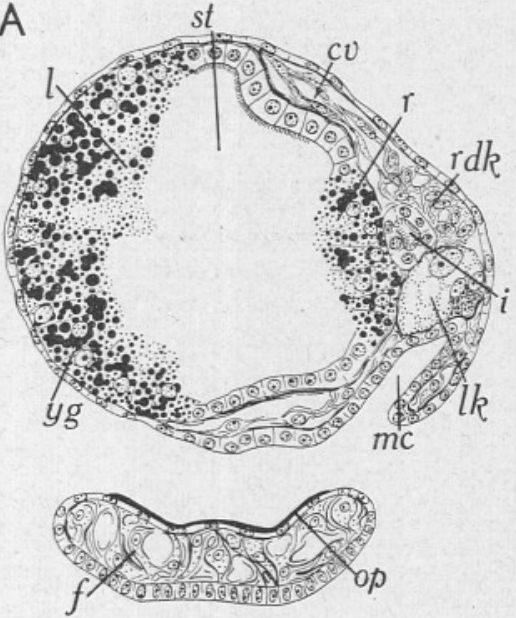

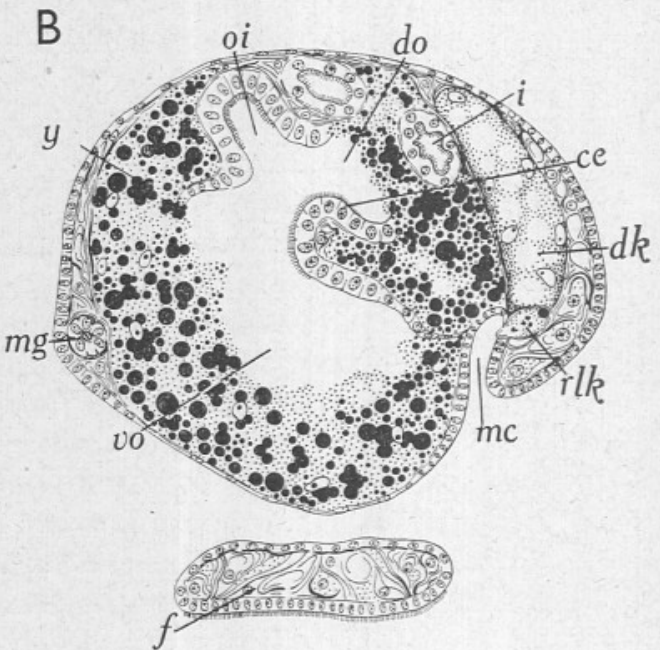

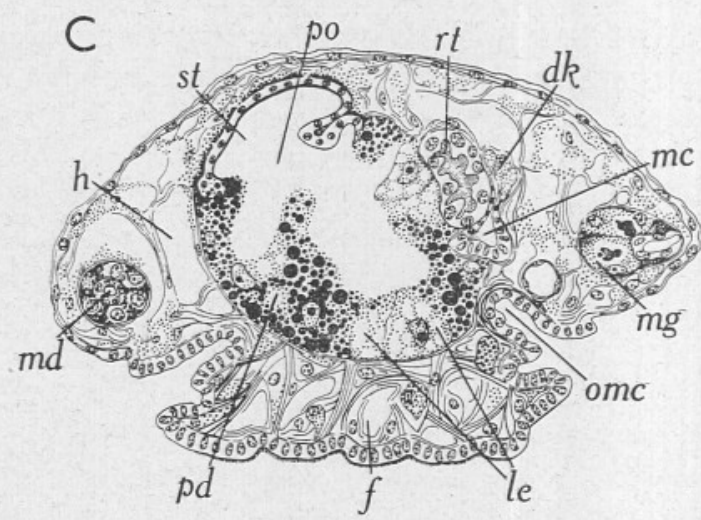

Fig. 6. A. Veliger. Transverse section through stomach and larval kidney: $\times 240$. B. Embryo at mid-detorsion. Transverse section through stomach and kidney: $\times 230$. C. Embryo at time of hatching. Transverse section to show kidney opening into tubular mantle cavity and opening of posterior lobe of digestive gland: $\times 207$. ce, ciliated epithelium of stomach; do, opening of right lobe of digestive gland; $h$, haemocoelic space; $l e$, lime and excretory cells forming; $m c$, mantle cavity; $m d$, duct of marginal gland; o $i$, origin of intestine; $p d$, posterior lobe of digestive gland; $p o$, opening of posterior lobe of digestive gland; $r t$, rectum; vo, opening of left lobe of digestive gland; $y g$, yolk granules. Other letters as in Fig. 5 . 
round hole at the posterior end of the body, between the foot and the mantle, and to the right of the middle line. The heart is in the adult position, on the right side and posterior, the auricle lying behind the ventricle, and the pulsation of the two chambers can be seen through the mantle.

The capsule wall is gradually weakened by the action of the radula, perhaps assisted by an enzyme, and as soon as it is punctured the embryo emerges. It is difficult to find these young animals in the sandy rock crevices. Only three have been seen in their natural habitat and these were creeping over the egg masses from which they had just emerged. They do not appear to cluster with the rest of the community in the crevice, for the smallest individuals found in any community were $2.6 \mathrm{~mm}$. in length and showed the characteristics of the adult, whereas the newly hatched forms are $\mathrm{I} \cdot 2 \mathrm{~mm}$. in length, and in them neither lung nor reproductive organs are formed and the kidney is a simple, unbranched sac lying on the right side posteriorly.

The alimentary canal shows all the features of the adult. A jaw is developed in the roof of the buccal cavity and behind this the dorsal ciliated channel runs back to the oesophagus; the rest of the buccal cavity is lined by a cuticle. Before passing through the nerve ring the oesophagus receives the openings of the salivary glands which have now migrated through the nerve ring; as yet no salivary duct is developed. The epithelium of the crop is covered by a cuticle, and the crop is closed from the stomach by a sphincter. Because of differential growth of the stomach wall the anterior liver openings, which occupied a dorsal and ventral position during detorsion, are now gradually regaining their original orientation of right and left, and are opening into the initial chamber. At this stage they are wide, with no duct. Behind them the triturating stomach is differentiated, the epithelium being covered by a thickening cuticle beneath which the dorsal and ventral plates are formed. The posterior liver opening is still ventral (Fig. 6C, po). The lobes of the digestive gland are branching to form the initial tubules, and in the crypts of these lime cells and excretory cells are forming (le). The body cavity is approximately circular in transverse section and bounded on each side by a muscular diaphragm; it is filled for the most part by the digestive system. The greater part of the digestive gland lies ventral to the gut and has not as yet spread over the intestine. This has lengthened and assumes the coilings of the adult, though the ventral caecum of the anterior intestine and the typhlosole cannot be distinguished. At the posterior end of the gizzard, and on the right side, the rectum $(r t)$ passes ventrally to open into the mantle cavity $(m c)$. This is a short tube which runs dorsally to the anus, and is ciliated except around its opening to the exterior $(o m c)$, where it is surrounded by a sphincter. To the right of the anus it sends a small diverticulum to the opening of the definitive kidney $(d k)$, and from this is derived the secondary ureter. In the adult this cavity has previously been called the rectum and its opening to the exterior the anus, but from its development it is clear that it is a reduced mantle cavity, and this explains the fact that both the alimentary 
canal and the kidney open into it (Fig. I B, $m c$ ), and that its opening is connected to the vaginal opening by a groove, the two being surrounded by common lips. The kidney is still a compact, pear-shaped mass, with a small central cavity, lying on the right of the rectum just behind the heart; the broader end is dorsal and the ventral end opens into the incipient secondary ureter. The heart and kidney are separated from the general body cavity by the right diaphragm. It is not until later in development that the kidney branches and spreads around the posterior wall of the rectum to the left side of the body, where it penetrates the haemocoelic spaces (Fig. 6C, $h$ ) between the left diaphragm and the body wall. Carried round by this growth the secondary ureter comes to open into the posterior wall of the mantle cavity (Fig. I B, su) instead of its right side, and into it the primary ureter projects as a long papilla $(u)$ which is slung from the walls by two lateral sheets of tissue. A small mass of undifferentiated cells which will give rise to the reproductive organs lies posterior to the stomach. No lung has yet been formed, and it would seem that as it opens separately from the mantle cavity it must arise as a separate and independent invagination of the mantle epithelium which grows inwards and forwards to come into intimate contact with the haemocoelic blood spaces around the kidney.

The smallest individual which has been seen in any adult community measured, as previously stated, $2.6 \mathrm{~mm}$. in length. It was found during midAugust and was presumably hatched from eggs laid in the previous season. The mantle cavity was relatively wide and still opened on the right side of the body, receiving just within the mouth of the opening, and anterior to the anus, the female aperture, and posteriorly the opening of the ureter. From the kidney a small diverticulum had spread around the posterior end of the body and penetrated the haemocoelic spaces on the left side. The pneumostome was posterior and to the right of the opening of the mantle cavity, and led through a short duct to a small and comparatively unbranched pulmonary sac. This was in contact with the kidney on the right side, and a tendency to spread around the posterior diverticulum was indicated.

\section{Discussion}

The mantle cavity of the typical mollusc contains a definite series of organs and into it opens a definite number of apertures. The structure of the veliger of Onchidella celtica is essentially comparable with that of a monotocardian prosobranch, except that no ctenidium and hence no osphradium are present, so that if it possesses a cavity homologous with the molluscan mantle cavity we should expect to find opening into it a single kidney, the anus and the genital aperture. The cavity which has already been described on the right side of the veliger agrees with this, except that no genital aperture has yet appeared. The cavity can therefore be taken as a true mantle cavity. During the metamorphosis of the larva into the adult the rotation due to detorsion rotates it from its original position on the right side of the body to a median 
position posteriorly, carrying the anus and kidney opening with it, and meanwhile it becomes converted into a narrow tubular space with its opening contracted into a small pore. The kidney spreads posteriorly around the mantle cavity and on to the left side of the body, bringing about the consequent migration of its opening into the mantle cavity which has already been described. The net result of all these changes is that at the end of metamorphosis the animal has a secondary bilateral symmetry, a type of reorganization which is of frequent occurrence in detorted gastropods accompanying the loss of shell and reduction of the visceral hump. The median opening at the posterior end of the body of Onchidella, which has previously been called the anus, is thus seen to be nothing more nor less than the opening of the mantle cavity in its new position, and what has been called the secondary opening of the excretory system into the rectum is nothing but a retention of the original opening of the kidney into the mantle cavity, as in all molluscs. The former interpretation of the relationship of these parts was obviously possible only so long as the real nature of the cavity was unknown. In the adult animal the female aperture also opens into the mouth of the mantle cavity and on its right side, providing a further clue as to the identity of this space. As the penis lies on the side of the animal's head anterior to the region affected by detorsion, it retains this position in the adult.

Since it is clear that the space into which the digestive, excretory and genital systems open is the homologue of the mantle cavity of other molluscs, then the cavity called the lung-the possession of which is one of the main reasons for regarding the Onchidiidae as pulmonate gastropods-must be a new structure, independently evolved and not homologous with the lung of the pulmonates. This being so the question now arises as to whether the Onchidiidae should not be regarded as opisthobranchs which have acquired a pulmonary cavity. Both Plate (I893) and Hoffmann (I929) would agree that whatever the anatomical specialization of the genus Onchidella may be it is at least typical of the Onchidiidae as regards its habitat; were the Onchidiidae, as Bergh (1885) suggests, true pulmonates they must be regarded as attempting to invade the sea from the land: on the former view the direction of migration would be reversed.

The opisthobranch affinities of the group have previously been recognized by Plate (I893) and Labbé (I934). The former assumes a tectibranch origin for the pulmonates and proposes to derive the Onchidiidae from the base of the pulmonate stem; the latter actually regards them as a group of opisthobranchs. The most important points in which these molluscs agree with the opisthobranchs are: (I) the reduction in size of the visceral hump; (2) the loss of the shell; (3) the posterior position of the mantle cavity; (4) the position of the auricle behind the ventricle; (5) the reduction of ganglia in the visceral loop to three; (6) the possession of three liver lobes, two anterior and one posterior; (7) the general disposition of the reproductive organs; (8) the veliger larva with its primary and secondary kidneys. On the other hand, it 
may be said with Bergh (1885) that the Onchidiidae possess a number of characters in common with the pulmonates, the most important of which are: (I) the possession of a lung; (2) the shortening of the visceral loop; (3) the retractile tentacles bearing eyes at their summits; (4) the loss of a seminal groove; (5) the development of thick chitinous plates in the stomach; (6) the number of lateral teeth on the radula. The occurrence of these features may, however, be explained in other ways: the lung in the two groups is not homologous; the shortening of the visceral loop is not confined to pulmonates, but is found in many nudibranchs; the development of eyes on the tentacles is indicated even in the prosobranch molluscs such as Buccinum and Nucella, though here the tentacles are not invaginable; in dorids the seminal groove is lost and these nudibranchs have also numerous lateral teeth on the radula. The stomach of the Onchidiidae is built on the typical prosobranch plan in that the crushing plates are developed in the stomach itself, and differs from that of the tectibranch where the plates are oesophageal and the stomach is reduced (Fretter, 1939). Its distinguishing features can be directly attributed to the quantities of sand which are ingested with the food (Heidermanns, I924).

It is generally recognized that the opisthobranchs are derived from monotocardian prosobranchs. The pulmonates and the opisthobranchs have retained only one set of the organs associated with the mantle cavity and so may have come either from closely related prosobranch groups or the pulmonates may have originated from an early group of the opisthobranchs themselves. If the latter be the case, then it may be suggested that the Onchidiidae separated from the opisthobranch stem at about the same time. From this origin, however, the Onchidiidae have evolved along different lines from the pulmonates, retaining more opisthobranch characters. Owing to adaptation to similar habitats they have acquired a superficial resemblance to the nudibranchs, and the acquisition of a lung, a structure independent of the true mantle cavity, has enabled them to become most active during intertidal periods, and so to exploit a habitat at a time when it is closed to other littoral gastropods. Even with this organ of terrestrial respiration their range is still restricted by their dependence on a relatively high humidity, although it is doubtful how serious this factor would be in limiting activity on the seashore. Many of the features which the Onchidiidae share with the pulmonates may be attributed to the close origin of the two groups, the similarity of their diet and their air-breathing habit. The pulmonary respiration of Onchidella celtica is by itself insufficient for the respiratory needs of the animal, but is a necessary supplement to pallial respiration when the animal is active.

The distribution of the Onchidiidae, the northern limit of which is the extreme south-western coasts of England, and likewise their inactivity during the winter months, suggest that they are unable to endure a low temperature. The tendency towards the adoption of a terrestrial mode of life has been intensified in other members of the group: some live above the intertidal zone and Onchis montana is definitely terrestrial. 
On the whole it would seem that the most suitable place to assign the group is with the opisthobranchs, regarding it as a small twig from the base of the main stem. This is in agreement with Labbé (1934), though he prefers the name Silicodermatae to Onchidacea. He states that in O. celtica spicules of silica are found in the connective tissue under the epidermis, the largest measuring $25 \mu$ and occupying a large part of the dermal tissue. In other species he describes the spicules as being much larger. No suggestion of such spicules has been found in $O$. celtica, nor could they be identified in the examination, which was kindly made by Mr A. G. Lowndes, of the nota of forty newly collected specimens. Unless the spicules are much more conspicuous in the other genera, the name Silicodermatae would appear to be a misnomer.

Mr Lowndes has given me the following note:

The material given to me was weighed, $3.397 \mathrm{~g}$. It was placed in a Kjeldahl flask together with about $100 \mathrm{ml}$. of concentrated sulphuric acid and a sufficient quantity of potassium sulphate. After boiling up the mixture for an hour a drop of mercury was added and the whole again boiled till the liquid in the flask became quite clear and colourless. When the contents of the flask were cool they were washed out into a $1000 \mathrm{ml}$. beaker and allowed to remain overnight. A small amount of sediment was to be seen on the bottom of the beaker. Nearly all the liquid was poured off and about $50 \mathrm{ml}$. of concentrated nitric acid added. The beaker was then filled with distilled water and allowed to stand for $4 \mathrm{hr}$. There was a small amount of sediment and it was examined in water both in a watch-glass and on a slide under a Zeiss D objective. The sediment was seen to consist of a few sand grains, a few identifiable sponge spicules and a very large number of diatom frustules. The length of the diatoms was found to be $8 \mu$ in most cases. There was also a small amount of matrix consisting of amorphous silica but no recognizable spicules other than those mentioned were found. [A. G. Lowndes.]

\section{SUMMARY}

Onchidella celtica lives in communities in intertidal rock crevices, emerging only when uncovered by the tide during the milder months (MarchNovember). It feeds on young algae and diatoms, rasping them from the rock with the radula which is lubricated by a mucous saliva. The distensible crop and stomach afford ample storage space for the food. The stomach consists of three chambers (Fig. 2), and the dorsal ( $d$ ) and ventral (v) chitinous plates of the posterior one, the gizzard, crush the contents and help to direct the soluble portion towards the ducts of the digestive gland. There are three of these-the two anterior $(l d, r d)$ are large and lead from the initial chamber of the stomach $(i c)$, the third $(p d)$ is small and joins the posterior wall of the gizzard ( $p w)$. The digestive gland secretes into the stomach; no cellulase occurs. Feeding experiments suggest that the digestive cells of the gland absorb only fluid. Lime and excretory cells occur in the crypts of the digestive epithelium, the latter concerned with taking up excretory matter from the blood and elaborating it into spherical masses for evacuation with the faeces. From the anterior ducts this waste matter, and that from the 
digestive cells, is directed to a small caecum (c), and so prevented from mixing with food in the stomach, and there is consolidated and cemented to the faecal rod which fills the intestine a few hours after a meal. The large quantity of indigestible and undigested food in the stomach is directed into the intestine by the mechanical action of the gizzard.

The mantle is solely responsible for respiration when the mollusc is covered by water or is inactive at low tide. At other times pulmonary supplements pallial respiration-the pneumostome (Fig. IA, $p$ ) is widely open during periods of activity and the cavity of the lung distended. The lung follows the course of the kidney; its walls are produced into fine diverticula which penetrate the nearby haemocoelic spaces (Fig. 3A), and the respiratory surface consists of parallel blood channels lined by squamous epithelium $(o s, i s, s c)$. $O$. celtica will survive in an atmosphere of $90 \%$ R.H. for three days without apparent effect.

The period of sexual activity extends over the summer months; egg capsules are laid during July, August and the beginning of September. The upper part of the hermaphrodite duct acts as a vesicula seminalis and here there is evidence of sperm absorption. Distally the duct divides into two channels, the oviduct (Fig. $4, o v$ ) and vas deferens (vd), which are glandular and share a common dorsal wall. Both are ciliated and the gland cells are subepithelial. At the beginning of the vas deferens a large diverticulum forms the prostate $(p r)$. The upper part of the oviduct bears six diverticula (I-VI) along which the eggs must travel. The first of these, the smallest, overhangs the fertilization chamber $(f c)$ and acts as a receptaculum seminis $(r s)$; the other five are of increasing size, and the sixth is wound into a spiral. The fertilization chamber receives the ducts of the albumen gland (dag). The two channels of the genital duct become entirely separated: the vas deferens forms a narrow non-glandular tube $\left(v d_{1}\right)$ and follows the external ciliated groove (Fig. I A, $c g$ ) on its way to the penis; the oviduct becomes less glandular and at the beginning of the muscular vagina (Fig. $4, v$ ) it receives the duct from the bursa copulatrix $(d b c)$ and, approximately opposite this, the duct of a glandular flagellum $(f)$.

The egg capsules are cemented to the walls of the rock crevices. Each is an elongated tube distended at regular intervals by an egg and coiled in a mucoid secretion. Each egg is surrounded by albumen, and by a capsule wall made of three distinct layers; the consistency and staining properties of these suggest that they are secreted by the diverticula of the oviduct (I-VI). The embedding mucoid secretion is probably produced by the pedal mucous gland (Fig. I A, $d c, v c$ ). Whilst in the egg capsule the egg develops into a typical prosobranch monotocardian veliger (Fig. $.5 \mathrm{~A}$ ) which undergoes detorsion and assumes the external appearance of the adult (Fig. $5 \mathrm{~B}, \mathrm{C}, \mathrm{D}$ ). At this stage it hatches. There is no lung and the kidney is a simple sac behind the heart. The lung appears to develop not from the mantle cavity, but as a separate invagination of the mantle epithelium behind this cavity. 
The embryological study shows that the tube which has previously been called the rectum is a reduced mantle cavity receiving the openings of the anus, the ureter and, at its mouth, the vagina. The new interpretation of the homologies of these parts calls for a revision of the systematic position of the Onchidiidae; its affinities with the prosobranchs are discussed and it is concluded that the family should be regarded as an early offshoot from the main stem of the opisthobranchs.

\section{REFERENCES}

Arey, L. B. \& Crozier, W. J., I92I. On the natural history of Onchidium. Fourn. Exp. Zool., Vol. xxxiI, pp. 443-502.

Bergh, R., I885. Ueber die Verwandtschaftsbeziehungen der Onchidien. Morph. $F b$., Bd. $x$, pp. I72-8I.

Brock, J., I883. Besprechung der Arbeit von Joyeux-Laffuie. Biol. Zbl., Bd.' III, pp. $370-4$.

Cuvier, G., I804. Mémoire sur l'Onchidie, genre de mollusques nus, voisin des Limaces, et sur une espèce nouvelle, Onchidium Peronii. Paris, Ann. Mus. Hist. nat., T. v, pp. 99-I22.

Ellis, A. E., I926. British Snails. Oxford, Clarendon Press.

Fischer, H., I892. Recherches sur la morphologie du foie des Gastéropodes. Bull. sci. Fr. Belg., T. XxIv (ser. 4, T. III), pp. 260-346.

Forbes, E. \& Hanley, S., I853. A History of British Mollusca and their Shells. London.

FRETTER, V., I937. The structure and function of the alimentary canal of some species of Polyplacophora (Mollusca). Trans. Roy. Soc. Edinb., Vol. LIX, pp. II9-64.

1939. The structure and function of the alimentary canal of some tectibranch molluscs, with a note on excretion. Trans. Roy. Soc. Edinb., Vol. LIx, pp. 599-646.

I94I. The genital ducts of some British stenoglossan prosobranchs. Fourn. Mar. Biol. Assoc. U.K., Vol. xxv, pp. I73-2 I I.

Graham, A., I932. On the structure and function of the alimentary canal of the limpet. Trans. Roy. Soc. Edinb., Vol. LVII, pp. 287-308.

Haller, B., I894. Betrachtungen über die Nieren von Onchidium celticum Cuv. Verh. naturh,-med. Ver. Heidelberg, N.F. Bd. v, pp. I-IO.

HeIDERmanNS, C., I924. Über den Muskelmagen der Süsswasserlungenschnecken. Zool. Fb. Abt. 3 Allg. Zool., Bd. XLI, pp. 335-424.

HIRASAKA, K., I 922 . On the structure of the dorsal eyes of Onchidium with notes on their formation. Annot. zool. jap., Vol. x, pp. I7I-8I.

Hoffmann, H., 1929. Zur Kenntnis der Oncidiiden (Gastrop. Pulmonés). Teil II. Phylogenie und Verbreitung. Zool. Fb. Abt. I Syst., Bd. LVII, pp. 253-302.

HowelLs, H. H., 1942. The structure and function of the alimentary canal of Aplysia punctata. Quart. Fourn. Micr. Sci., Vol. LxxxII, pp. 357-97.

Jhering, H. von, 1877. Ueber die systematische Stellung von Peronia, und die Ordnung der Nephropneusta. Erlangen, Sitzber. Phys. Med. Soc., Bd. 9, pp. I3 I-68.

JoyeuX-LAFfuie, J., I882. Organisation et développement de l'Oncidie Oncidium celticum Cuv. Arch. Zool. exp. gén., Vol. x, pp. 225-383.

LABBÉ, A., I934. Opisthobranches et Silicodermes (Oncidiades). Rés. sci. Voy. Indes orientales néerl. Prince Léopold Belg., Vol. II, fasc. I4 (i), pp. I-83.

LINKE, O., I933. Morphologie und Physiologie des Genitalapparates des Nordseelittorinen. Wiss. Meeresuntersuch., Vol. xIx, no. 5, 60 pp. 
MazZarelli, G., 1906. Contributo alla conoscenza delle larve libere degli opisthobranchi. Arch. zool. ital. Napoli, Vol. II, pp. 19-78.

Plate, L., I893. Studien über opisthopneumone Lungenschnecken. II. Die Oncidiiden. Zool. Fb. Abt. 2 Anat., Bd. viI, pp. 93-234.

SEMPER, C., 1876-7. Einige Bemerkungen über die "Nephropneusten" von v. Jherings. Arb. Zool. zool. Inst. Würzburg, Bd. III.

Wissel, K. voN, 1898. Beiträge zur Anatomie der Gattung Oncidiella. Zool. $\mathfrak{F}$ b., suppl. Bd. IV (Fauna Chilensis, Bd. I), pp. 583-640. 